BMC

\title{
Genomics
}

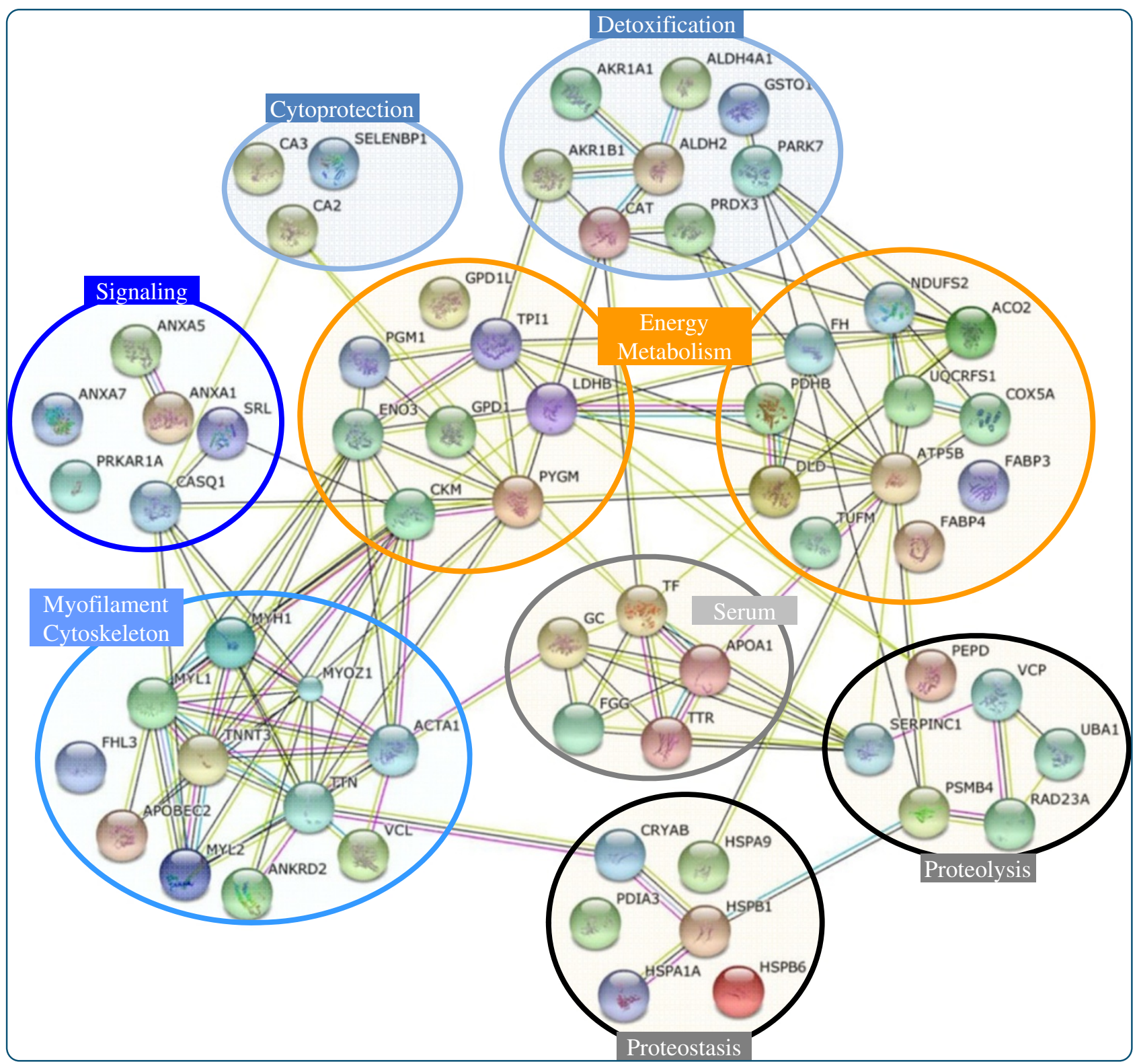

\section{Proteomics of muscle chronological ageing in post-menopausal women}

Gueugneau et al. 


\title{
Proteomics of muscle chronological ageing in post-menopausal women
}

Marine Gueugneau ${ }^{1,2,7}$, Cécile Coudy-Gandilhon ${ }^{1,2}$, Ophélie Gourbeyre ${ }^{1,2}$, Christophe Chambon ${ }^{3}$, Lydie Combaret ${ }^{1,2}$, Cécile Polge ${ }^{1,2}$, Daniel Taillandier ${ }^{1,2}$, Didier Attaix ${ }^{1,2}$, Bertrand Friguet $^{4}$, Andrea B Maier ${ }^{5}$, Gillian Butler-Browne ${ }^{6}$ and Daniel Béchet ${ }^{1,2^{*}}$

\begin{abstract}
Background: Muscle ageing contributes to both loss of functional autonomy and increased morbidity. Muscle atrophy accelerates after 50 years of age, but the mechanisms involved are complex and likely result from the alteration of a variety of interrelated functions. In order to better understand the molecular mechanisms underlying muscle chronological ageing in human, we have undertaken a top-down differential proteomic approach to identify novel biomarkers after the fifth decade of age.
\end{abstract}

Results: Muscle samples were compared between adult (56 years) and old (78 years) post-menopausal women. In addition to total muscle extracts, low-ionic strength extracts were investigated to remove high abundance myofibrillar proteins and improve the detection of low abundance proteins. Two-dimensional gel electrophoreses with overlapping IPGs were used to improve the separation of muscle proteins. Overall, 1919 protein spots were matched between all individuals, 95 were differentially expressed and identified by mass spectrometry, and they corresponded to 67 different proteins. Our results suggested important modifications in cytosolic, mitochondrial and lipid energy metabolism, which may relate to dysfunctions in old muscle force generation. A fraction of the differentially expressed proteins were linked to the sarcomere and cytoskeleton (myosin light-chains, troponin T, ankyrin repeat domain-containing protein-2, vinculin, four and a half LIM domain protein-3), which may account for alterations in contractile properties. In line with muscle contraction, we also identified proteins related to calcium signal transduction (calsequestrin-1, sarcalumenin, myozenin-1, annexins). Muscle ageing was further characterized by the differential regulation of several proteins implicated in cytoprotection (catalase, peroxiredoxins), ion homeostasis (carbonic anhydrases, selenium-binding protein 1) and detoxification (aldo-keto reductases, aldehyde dehydrogenases). Notably, many of the differentially expressed proteins were central for proteostasis, including heat shock proteins and proteins involved in proteolysis (valosin-containing protein, proteasome subunit beta type-4, mitochondrial elongation factor-Tu).

Conclusions: This study describes the most extensive proteomic analysis of muscle ageing in humans, and identified 34 new potential biomarkers. None of them were previously recognized as differentially expressed in old muscles, and each may represent a novel starting point to elucidate the mechanisms of muscle chronological ageing in humans.

Keywords: Human, Skeletal muscle, Ageing, Sarcopenia, Proteomics, Biomarkers

\footnotetext{
* Correspondence: daniel.bechet@clermont.inra.fr

${ }^{1}$ INRA, UMR 1019, Centre de Recherche en Nutrition Humaine, Université

d'Auvergne, F-63122 Saint Genès Champanelle, France

${ }^{2}$ Clermont Université, Université d'Auvergne, F-63000 Clermont-Ferrand,

France

Full list of author information is available at the end of the article
}

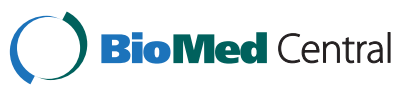

(c) 2014 Gueugneau et al.; licensee BioMed Central. This is an Open Access article distributed under the terms of the Creative Commons Attribution License (http://creativecommons.org/licenses/by/4.0), which permits unrestricted use, distribution, and reproduction in any medium, provided the original work is properly credited. The Creative Commons Public Domain Dedication waiver (http://creativecommons.org/publicdomain/zero/1.0/) applies to the data made available in this article, unless otherwise stated. 


\section{Background}

Ageing affects most tissues and physiologic functions, and one of the most affected organs is the skeletal muscle. The progressive decline in muscle mass and function due to ageing, which is also referred to as sarcopenia [1], contributes to both loss of autonomy [2], increased prevalence of falls, decreased resistance to metabolic aggression that increases morbidity [3] and mortality [4]. Numerous theories have been proposed to explain muscle ageing. Obviously, this is a multifactorial phenomenon which implicates intrinsic factors such as perturbations in the endocrine system, neuronal remodelling, oxidative stress and deficiencies in muscle regeneration, extrinsic factors such as diet and exercise, and also probably other unknown mechanisms [5].

Age-related degenerative changes are reflected in alterations in muscle morphology, function, and biochemical properties. Muscle ageing is thus associated with muscle fiber atrophy [6,7], reduced muscle regenerative capacity [8], and neuropathic processes leading to motor unit denervation [9]. Mitochondrial dysfunctions with decreased capacity of oxidative enzymes and a decline of mitochondrial ATP production may also be observed with ageing in skeletal muscles [10-12].

The overall functional, structural, and biochemical alterations in ageing muscle have been extensively studied, but the molecular mechanisms implicated remain to be specified. The differential expression profiles of mRNAs constitute a first essential level of information, but analyses of the expression profile of proteins in ageing are also required to understand the molecular mechanisms important for the muscle ageing process [13]. In fact, unlike the genome, the proteome varies in response to many physiological or pathological factors. In addition, the proteome is orders of magnitude more complex than the transcriptome due to post-translational modifications, protein oxidation or limited protein degradation [14].

Several studies have been conducted in rat muscle and proteomic profiling has demonstrated substantial alterations in muscle proteins involved in key metabolic pathways, myofibrillar remodelling, cytoskeleton organisation and mechanisms of cytoprotection and cytodetoxification [15-19]. However, few studies have been conducted with human muscle and results are contradictory. Gelfi et al. [20] have shown that several enzymes involved in oxidative metabolism, including ubiquinol-cytochrome c reductase or aspartate aminotransferase, were more abundant in elderly than in young people, while Short et al. [11] have demonstrated a decrease in these enzymes with ageing. In contrast, some results observed in rat muscle proteomic analyses were confirmed in human muscle, such as a decrease in enzymes involved in glycolytic metabolism and an increase in proteins involved in cytoprotection (carbonic anhydrase 3) and cytodetoxification (Hsp70) [20,21].
Because epidemiological studies have indicated accelerated muscle wasting after the fifth decade with an approximately $2 \%$ reduction in muscle mass per year [22], we have undertaken a top-down differential proteomic approach to determine potential changes after the fifth decade of life and to identify novel biomarkers of muscle ageing. In a previous study, we used a shot-gun proteomics approach to identify 35 potential biomarkers [23]. Herein, we performed two dimensional gel electrophoreses (2DGE) using biopsies of vastus lateralis from mature adult (56 years) vs. old (78 years) women, and for better separation of proteins, two different strategies were conducted. Firstly, overlapping immobilized $\mathrm{pH}$ gradient (IPG) with three different $\mathrm{pH}$ ranges were used to improve muscle proteins separation, and secondly, we assessed low salt extracts to remove the high abundance myofibrillar proteins and improve the detection of low abundance proteins. The proteomic profiling of aged skeletal muscle fibers revealed a differential expression pattern of 67 potential biomarkers important for energy metabolism, contractile properties, calcium signaling, cytoprotection, regulation of protein misfolding, and proteolysis. The present study demonstrates that alterations of muscle function in elderly women are associated with severe perturbed protein expression patterns and identified 34 new potential biomarkers of sarcopenia that had not previously been described.

\section{Results and discussion}

\section{Differentially expressed proteins during ageing}

In order to evaluate age-dependent alterations in the skeletal muscle proteome after the fifth decade of life, total muscle extracts from biopsies of mature adult (56 years) versus old (78 years) post-menopausal women were resolved by $2 \mathrm{DGE}$. Gels with overlapping range of IPGs were used to improve the separation of total muscle extracts. 2DGE with medium range IPGs ( $\mathrm{pH} 5-8)$ revealed 839 protein spots that were matched between all individuals. Among these protein spots, 56 were found to be differentially expressed between adult and old women, and 31 were identified by liquid chromatography coupled to tandem mass spectrometry (LC-MS/MS), corresponding to 27 different proteins (Figure 1A). 2DGE with acidic IPGs (pH 3.0-5.6) distinguished 202 matched protein spots, and among them 8 were differentially expressed and identified as 6 different proteins (Figure 1B). Narrow IPGs were also used to achieve optimal resolution in the pH 5.3-6.5 range, and this revealed a further 179 matched spots. Among these 179 spots, statistical analysis revealed 3 differentially expressed spots which were identified by LC-MS/MS as 3 different proteins (Figure 1C).

Because myofibrillar proteins may hamper the detection of low abundance proteins, we also precipitated myofibrils at low ionic strength $[24,25]$, and focused on 


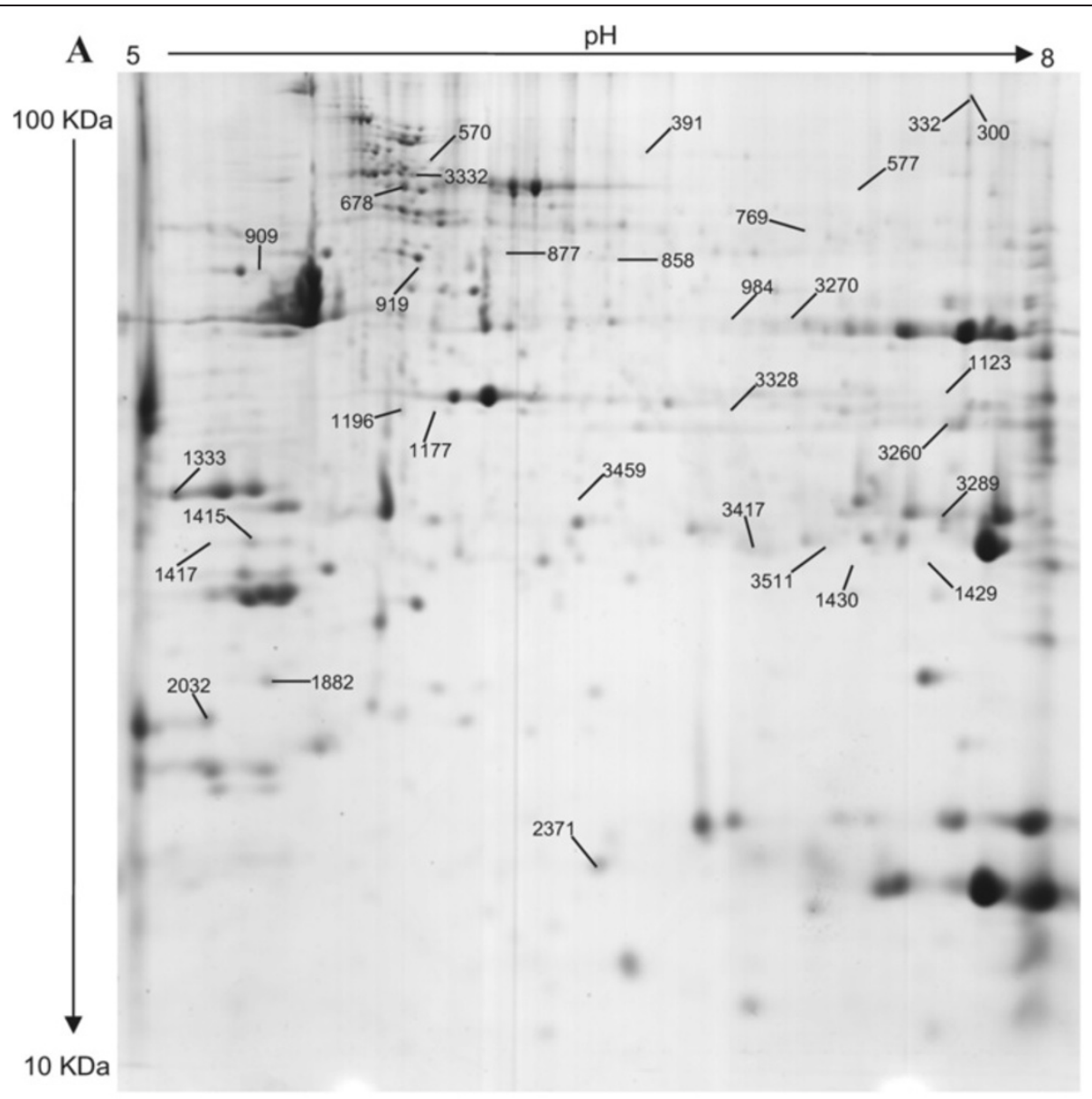

B

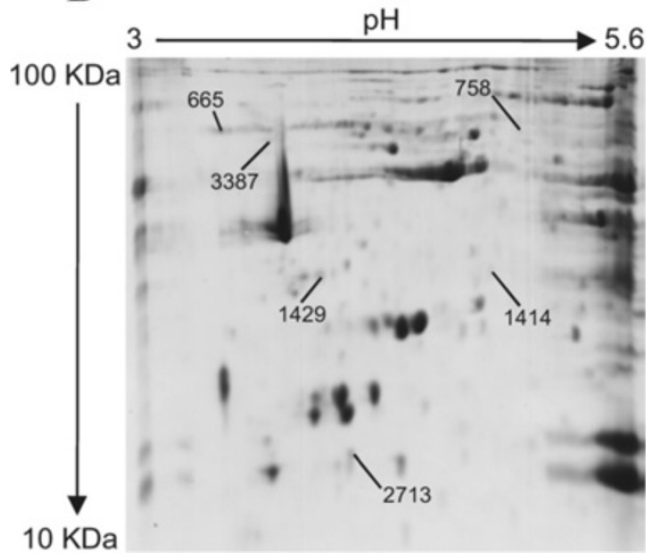

C

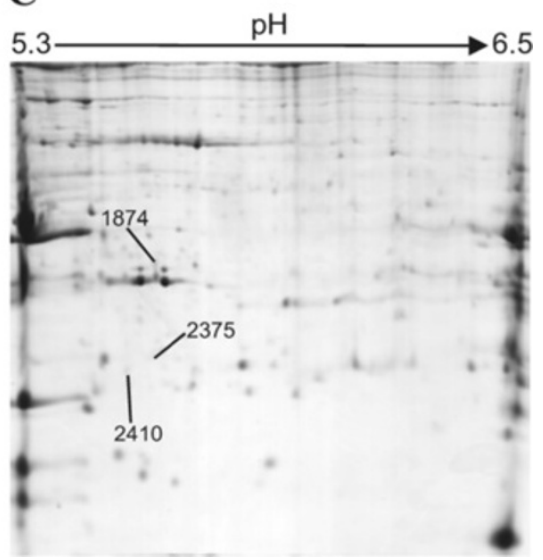

Figure 1 Representative 2DGE image obtained from total protein extracts of human vastus lateralis skeletal muscle. 2DGE was performed using a pH range of 5-8 (A), 3-5.6 (B) or 5.6-6.5 (C) in first dimension and SDS-PAGE (11\%T) in the second. Protein loading was 700 $\mu \mathrm{g}$, and the gels were stained using colloidal Coomassie blue G-250. Differentially expressed and identified proteins are marked and spot numbers refer to Table 1.

the soluble low ionic strength (LIS) extract. Thirty-six gels with medium range IPGs $(\mathrm{pH} 5-8)$ were used to analyze LIS extracts and 699 protein spots were matched between all individuals. Statistical analysis revealed that
86 spots were differentially expressed between adult and old women. Among them, 55 were identified by LC-MS/MS (Figure 2), and they corresponded to 37 different proteins. Targeting the LIS sub-proteome improved the 2DGE 


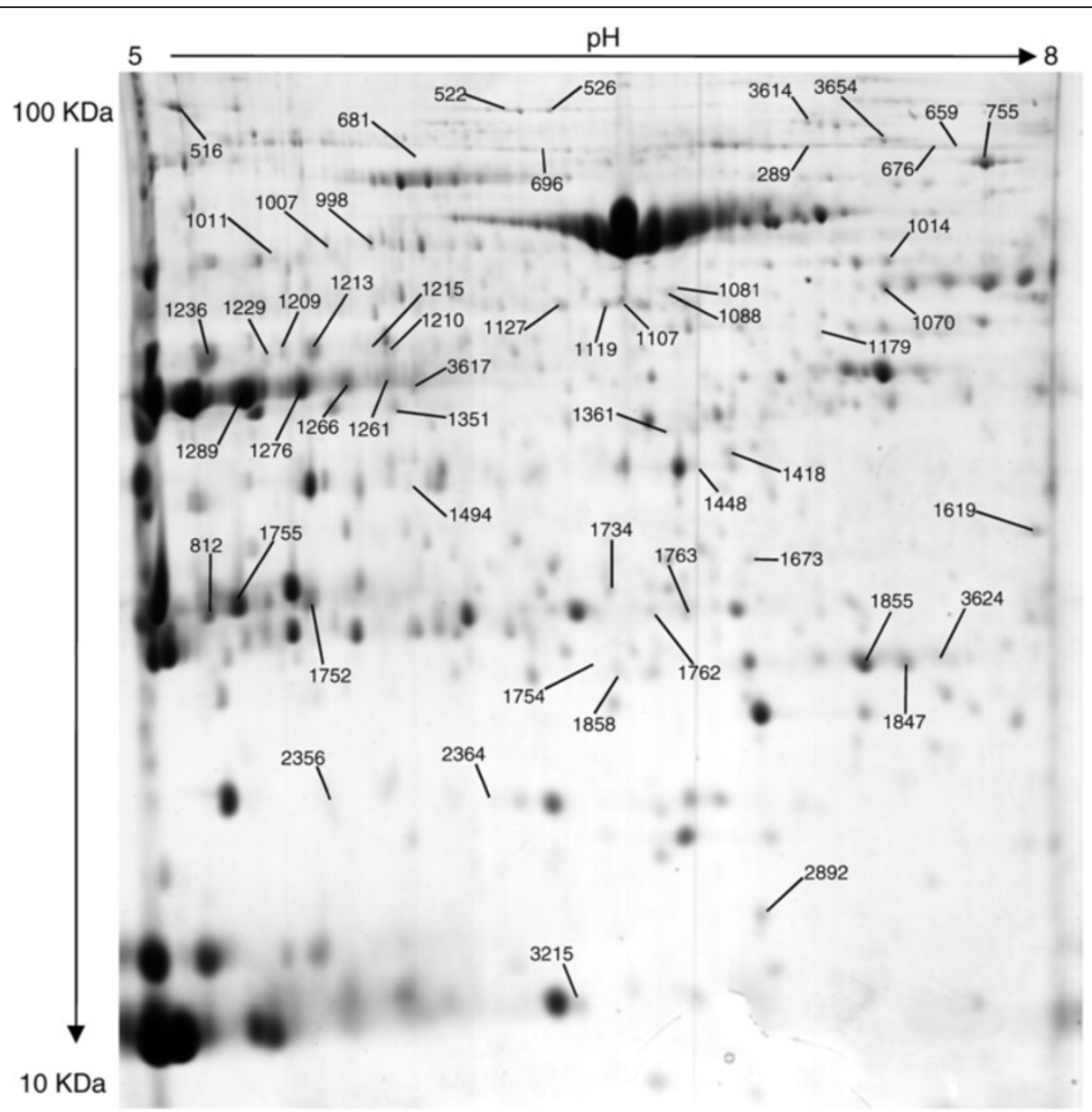

Figure 2 Representative 2DGE image obtained from low ionic strength (LIS) extracts of human vastus lateralis skeletal muscle. 2DGE was performed using a pH range of 5-8 in the first dimension and SDS-PAGE (11\%T) in the second. Protein loading was $700 \mu \mathrm{g}$, and the gels were stained using colloidal Coomassie blue G-250. Differentially expressed and identified proteins are marked and spot numbers refer to Table 2.

analysis of the muscle proteome, as most (32 out of 37) differentially expressed LIS proteins were not found in total muscle extracts.

Interestingly, shot-gun proteomics previously identified 35 potential biomarkers in the LIS sub-proteome [23]. It should be noted that, although shot-gun and 2DGE proteomics are based on different strategies (analyses of tryptic digests and intact protein isoforms, respectively), the two techniques are complementary, as only 6 common proteins were found in both investigations: titin (TTN), ankyrin repeat domain-containing protein 2 (ANKRD2), L-lactate dehydrogenase $\beta$ (LDHB), furamate hydratase (FH), fatty acid binding protein 4 (FABP4) and carbonic anhydrase 3 (CA3). Overall in the present 2DGE study, 1919 protein spots were matched between all individuals, 95 were differentially expressed and identified, and they corresponded to 67 different proteins. Table 1 (for total muscle extract) and Table 2 (for LIS extract) summarize the main properties of the proteins differentially regulated in skeletal muscle between adult and old post-menopausal women. Absolute fold changes varied from 1.1 to 2.6. Even though some fold-changes appeared relatively small, there were parallel changes of several components in each pathway or biological process, suggesting some important coordinated and specific regulations.

\section{Perturbations of the myofilament network and cytoskeleton with ageing \\ Sarcomeric proteins}

Muscle contraction is generated by an interaction between the molecular motor myosin and filamentous actin. Myosin is a hexameric protein that consists of two heavy chain subunits, two alkali light chain subunits and two regulatory light chain subunits. Myosin light chains typically exhibit various isoforms, and in our study, muscle ageing was associated with higher level of one myosin light chain $1 / 3$ skeletal muscle isoform (MYL1, spot 1882) and lower level of one myosin regulatory light chain 2 ventricular/cardiac muscle isoform (MYL2, spot 2032). Perturbations in myofibrillar contractile proteins were 
Table 1 Differentially expressed muscle proteins in total extract between adult ( $56 \mathrm{yr}$ ) and old (78 yr) post-menauposal women

\begin{tabular}{|c|c|c|c|c|c|c|c|c|c|c|}
\hline $\begin{array}{l}\text { 2DGE } \\
\mathrm{pH}\end{array}$ & $\begin{array}{l}\text { Spot } \\
n^{\circ}\end{array}$ & Accession & Symbol & Protein name & $\begin{array}{l}\text { Fold } \\
\text { change }\end{array}$ & $\begin{array}{l}\text { Age effect ( } p \\
\text { value) }\end{array}$ & $\begin{array}{l}\text { Mascot } \\
\text { score }\end{array}$ & $\begin{array}{l}\text { Sequence } \\
\text { coverage (\%) }\end{array}$ & $\begin{array}{l}\text { Unique } \\
\text { peptides }\end{array}$ & Main biological function \\
\hline 5-8 & 1882 & P05976 & MYL1 & Myosin light chain $1 / 3$ & +1.4 & 0.020 & 693 & 41 & 5 & Myofilaments and cytoskeleton \\
\hline 5-8 & 2032 & P10916 & MYL2 & Myosin regulatory light chain 2 & -1.7 & 0.012 & 4807 & 86 & 15 & Myofilaments and cytoskeleton \\
\hline 5-8 & 1123 & P45378 & TNNT3 & Troponin T, fast skeletal muscle & +1.9 & 0.033 & 288 & 24 & 4 & Myofilaments and cytoskeleton \\
\hline 5-8 & 1333 & P68133 & ACTA1 & Actin, alpha skeletal muscle ( $\mathrm{N}$-term fragment) & +1.7 & 0.042 & 999 & 23 & 4 & Myofilaments and cytoskeleton \\
\hline $5-8$ & 1415 & P68133 & ACTA1 & Actin, alpha skeletal muscle ( $\mathrm{N}$-term fragment) & +1.3 & 0.034 & 847 & 29 & 4 & Myofilaments and cytoskeleton \\
\hline 5-8 & 1417 & P68133 & ACTA1 & Actin, alpha skeletal muscle (C-term fragment) & +1.3 & 0.041 & 350 & 19 & 4 & Myofilaments and cytoskeleton \\
\hline 5-8 & 570 & P12882 & MYH1 & Myosin-1 (C-term fragment) & +2.3 & 0.011 & 712 & 9 & 11 & Myofilaments and cytoskeleton \\
\hline 3-5.6 & 665 & P31415 & CASQ1 & Calsequestrin-1 & +1.4 & 0.045 & 1146 & 22 & 9 & Signal transduction \\
\hline 5-8 & 858 & Q86TD4 & SRL & Sarcalumenin (mature C-term) & -1.6 & 0.008 & 1606 & 44 & 17 & Signal transduction \\
\hline 5-8 & 3260 & Q9NP98 & MYOZ1 & Myozenin-1 & +1.7 & 0.008 & 435 & 22 & 4 & Signal transduction \\
\hline 3-5.6 & 758 & P20073 & ANXA7 & Annexin A7 & +1.8 & 0.029 & 954 & 15 & 6 & Signal transduction, autophagy \\
\hline 5-8 & 300 & P06732 & CKM & Creatine kinase M-type (dimer) & -1.7 & 0.031 & 445 & 25 & 7 & Energy metabolism \\
\hline $5-8$ & 332 & P06732 & CKM & Creatine kinase M-type (dimer) & -1.7 & 0.048 & 737 & 39 & 11 & Energy metabolism \\
\hline 5-8 & 391 & P11217 & PYGM & Glycogen phosphorylase, muscle form & -2.6 & 0.031 & 1516 & 39 & 23 & $\begin{array}{l}\text { Energy metabolism, } \\
\text { glycogenolysis }\end{array}$ \\
\hline $5.3-6.5$ & 1874 & P21695 & GPD1 & $\begin{array}{l}\text { Glycerol-3-phosphate dehydrogenase [NAD+], } \\
\text { cytoplasmic }\end{array}$ & -1.4 & 0.040 & 3383 & 53 & 17 & Energy metabolism, shuttle \\
\hline $5-8$ & 3459 & Q8N335 & GPD1L & $\begin{array}{l}\text { Glycerol-3-phosphate dehydrogenase 1-like } \\
\text { protein }\end{array}$ & -1.4 & 0.022 & 1884 & 55 & 14 & $\begin{array}{l}\text { Energy metabolism, shuttle, } \\
\text { hypoxia }\end{array}$ \\
\hline $5-8$ & 3511 & P60174 & TPI1 & Triosephosphate isomerase & +1.3 & 0.050 & 798 & 56 & 9 & $\begin{array}{l}\text { Energy metabolism, glycolysis, } \\
\text { detoxification }\end{array}$ \\
\hline $5-8$ & 1196 & P11177 & PDHB & $\begin{array}{l}\text { Pyruvate dehydrogenase E1 component subunit } \\
\text { beta }\end{array}$ & -1.3 & 0.043 & 2267 & 59 & 14 & Energy metabolism, Krebs cycle \\
\hline 5-8 & 769 & P09622 & DLD & Dihydrolipoyl dehydrogenase, mitochondrial & -1.4 & 0.010 & 466 & 29 & 8 & Energy metabolism, Krebs cycle \\
\hline 5-8 & 577 & Q99798 & $\mathrm{ACO} 2$ & Aconitate hydratase, mitochondrial & -1.6 & 0.043 & 365 & 19 & 9 & Energy metabolism, Krebs cycle \\
\hline $5-8$ & 984 & O75306 & NDUFS2 & $\begin{array}{l}\text { NADH dehydrogenase [ubiquinone] iron-sulfur } \\
\text { protein 2, mitochondrial }\end{array}$ & -1.6 & 0.005 & 1777 & 49 & 15 & $\begin{array}{l}\text { Energy metabolism, oxidative } \\
\text { phosphorylation }\end{array}$ \\
\hline $5-8$ & 3417 & P47985 & UQCRFS1 & $\begin{array}{l}\text { Cytochrome b-c1 complex subunit Rieske, } \\
\text { mitochondrial }\end{array}$ & -1.3 & 0.031 & 1271 & 23 & 5 & $\begin{array}{l}\text { Energy metabolism, oxidative } \\
\text { phosphorylation }\end{array}$ \\
\hline 3-5.6 & 2713 & P20674 & $\operatorname{cox} 5 \mathrm{~A}$ & Cytochrome c oxidase subunit $5 \mathrm{~A}$, mitochondrial & -1.5 & 0.015 & 779 & 48 & 6 & $\begin{array}{l}\text { Energy metabolism, oxidative } \\
\text { phosphorylation }\end{array}$ \\
\hline $5-8$ & 909 & P06576 & ATP5B & ATP synthase subunit beta & -1.4 & 0.023 & 2725 & 62 & 20 & $\begin{array}{l}\text { Energy metabolism, oxidative } \\
\text { phosphorylation }\end{array}$ \\
\hline $5-8$ & 2371 & P05413 & FABP3 & Fatty acid-binding protein, heart & -1.4 & 0.004 & 2281 & 77 & 11 & $\begin{array}{l}\text { Energy metabolism, lipid } \\
\text { transport }\end{array}$ \\
\hline 5-8 & 3328 & P15121 & AKR1B1 & Aldose reductase & -1.5 & 0.016 & 323 & 31 & 5 & Detoxification, cytoprotection \\
\hline
\end{tabular}


Table 1 Differentially expressed muscle proteins in total extract between adult (56 yr) and old (78 yr) post-menauposal women (Continued)

\begin{tabular}{|c|c|c|c|c|c|c|c|c|c|c|}
\hline 3-5.6 & 1414 & P04792 & HSPB1 & Heat shock protein beta-1 & +1.7 & 0.019 & 714 & 36 & 5 & Detoxification, cytoprotection \\
\hline $5.3-6.5$ & 2375 & P04792 & HSPB1 & Heat shock protein beta-1 & +1.3 & 0.026 & 484 & 41 & 6 & Detoxification, cytoprotection \\
\hline 5-8 & 678 & P08107 & HSPA1A & Heat shock $70 \mathrm{kDa}$ protein $1 \mathrm{~A} / 1 \mathrm{~B}$ & +1.1 & 0.014 & 3630 & 52 & 14 & Detoxification, cytoprotection \\
\hline $5-8$ & 3332 & P38646 & HSPA9 & Stress-70 protein, mitochondrial & +1.4 & 0.008 & 5401 & 45 & 22 & Detoxification, cytoprotection \\
\hline 5-8 & 3289 & P00918 & CA2 & Carbonic anhydrase 2 & +1.3 & 0.047 & 1605 & 54 & 11 & Detoxification, cytoprotection \\
\hline 5-8 & 877 & Q13228 & SELENBP1 & Selenium-binding protein 1 & -1.5 & 0.028 & 1677 & 56 & 19 & Detoxification, cytoprotection \\
\hline $5.3-6.5$ & 2410 & P28070 & PSMB4 & Proteasome subunit beta type- 4 & -1.4 & 0.049 & 1692 & 33 & 5 & Proteolysis \\
\hline 3-5.6 & 3387 & P54725 & RAD23A & UV excision repair protein RAD23 homolog A & -1.3 & 0.041 & 309 & 28 & 6 & Proteolysis \\
\hline $5-8$ & 3270 & P49411 & TUFM & Elongation factor Tu, mitochondrial & -1.4 & 0.001 & 1548 & 38 & 12 & Protein synthesis, proteolysis \\
\hline 5-8 & 919 & P02679 & FGG & Fibrinogen gamma chain & -1.3 & 0.026 & 1023 & 59 & 16 & Serum \\
\hline $5-8$ & 1429 & P30042 & C21orf33 & ES1 protein homolog, mitochondrial & -1.6 & 0.001 & 364 & 51 & 6 & Miscellaneous \\
\hline 5-8 & 1430 & P30042 & C21orf33 & ES1 protein homolog, mitochondrial & -1.7 & 0.002 & 118 & 18 & 3 & Miscellaneous \\
\hline $5-8$ & 1177 & Q9HOPO & NT5C3 & Cytosolic 5'-nucleotidase 3 & -1.6 & 0.015 & 589 & 35 & 10 & Miscellaneous \\
\hline 3-5.6 & 1429 & Q9Y235 & APOBEC2 & $\begin{array}{l}\text { Apolipoprotein B mRNA-editing enzyme, catalytic } \\
\text { polypeptide-like } 2\end{array}$ & -1.2 & 0.018 & 1904 & 74 & 11 & Miscellaneous \\
\hline
\end{tabular}


Table 2 Differentially expressed muscle proteins in low ionic strength (LIS) extract between adult (56 yr) and old (78 yr) post-menauposal women

\begin{tabular}{|c|c|c|c|c|c|c|c|c|c|}
\hline $\begin{array}{l}\text { Spot } \\
n^{\circ}\end{array}$ & Accession & Symbol & Protein name & $\begin{array}{l}\text { Fold } \\
\text { change }\end{array}$ & $\begin{array}{l}\text { Age effect ( } p \\
\text { value) }\end{array}$ & $\begin{array}{l}\text { Mascot } \\
\text { score }\end{array}$ & $\begin{array}{l}\text { Sequence } \\
\text { coverage }(\%)\end{array}$ & $\begin{array}{l}\text { Unique } \\
\text { peptides }\end{array}$ & Main biological function \\
\hline 1734 & E7ENC6 & TTN & Titin (C-term fragment) & -1.4 & 0.032 & 4511 & 1 & 11 & Myofilaments and cytoskeleton \\
\hline 1361 & Q9GZV1 & ANKRD2 & Ankyrin repeat domain-containing protein 2 & +1.8 & 0.033 & 1831 & 51 & 14 & Myofilaments and cytoskeleton \\
\hline 522 & P18206-2 & VCL & Vinculin, isoform 1 & +1.5 & 0.048 & 1457 & 21 & 17 & Myofilaments and cytoskeleton \\
\hline 526 & P18206-2 & VCL & Vinculin, isoform 1 & +1.6 & 0.026 & 1329 & 26 & 20 & Myofilaments and cytoskeleton \\
\hline 1418 & Q13643 & FHL3 & Four and a half LIM domains protein 3 & -1.5 & 0.038 & 1046 & 42 & 8 & Myofilaments and cytoskeleton \\
\hline 1179 & P10644 & PRKAR1A & $\begin{array}{l}\text { CAMP-dependent protein kinase type I-alpha } \\
\text { regulatory subunit }\end{array}$ & +1.6 & 0.021 & 903 & 37 & 11 & Signal transduction \\
\hline 1494 & P04083 & ANXA1 & Annexin A1 & +1.3 & 0.049 & 4205 & 59 & 17 & Signal transduction, dystrophies \\
\hline 1619 & P08758 & ANXA5 & Annexin A5 & +1.5 & 0.005 & 3264 & 64 & 16 & $\begin{array}{l}\text { Signal transduction, membrane } \\
\text { repair }\end{array}$ \\
\hline 1673 & P78417 & GSTO1 & Glutathione S-transferase omega-1 & -1.5 & 0.049 & 674 & 44 & 7 & Detoxification, signal transduction \\
\hline 1261 & P06732 & CKM & Creatine kinase M-type & -1.3 & 0.019 & 3974 & 45 & 15 & Energy metabolism \\
\hline 1266 & P06732 & CKM & Creatine kinase M-type & -1.2 & 0.044 & 6576 & 50 & 16 & Energy metabolism \\
\hline 1276 & P06732 & CKM & Creatine kinase M-type & -1.2 & 0.017 & 8749 & 57 & 17 & Energy metabolism \\
\hline 1289 & P06732 & CKM & Creatine kinase M-type & -1.1 & 0.044 & 10394 & 52 & 17 & Energy metabolism \\
\hline 3617 & P06732 & CKM & Creatine kinase M-type & -1.4 & 0.037 & 3259 & 43 & 13 & Energy metabolism \\
\hline 516 & P06732 & CKM & Creatine kinase M-type (trimer) & -1.2 & 0.022 & 5360 & 54 & 16 & Energy metabolism \\
\hline 289 & P11217 & PYGM & Glycogen phosphorylase, muscle form & +1.4 & 0.019 & 3091 & 48 & 28 & Energy metabolism, glycogenolysis \\
\hline 659 & F5GZH7 & PYGM & Phosphorylase & +1.3 & 0.027 & 4260 & 49 & 31 & Energy metabolism, glycogenolysis \\
\hline 676 & F5GZH7 & PYGM & Phosphorylase & +1.7 & 0.004 & 662 & 24 & 12 & Energy metabolism, glycogenolysis \\
\hline 696 & F5GZH7 & PYGM & Phosphorylase & +1.5 & 0.004 & 917 & 23 & 15 & Energy metabolism, glycogenolysis \\
\hline 998 & P36871 & PGM1 & Phosphoglucomutase-1 & -1.3 & 0.017 & 1772 & 33 & 14 & Energy metabolism, glycogenolysis \\
\hline 1209 & P13929 & ENO3 & Beta-enolase & -1.3 & 0.005 & 3382 & 41 & 12 & Energy metabolism, glycolysis \\
\hline 1210 & P13929 & ENO1/3 & Alpha/beta-enolase & -1.7 & 0.027 & 5218 & 53 & 12 & Energy metabolism, glycolysis \\
\hline 1213 & P13929 & ENO3 & Beta-enolase & -1.3 & 0.044 & 9731 & 62 & 20 & Energy metabolism, glycolysis \\
\hline 1215 & P13929 & ENO3 & Beta-enolase & -1.6 & 0.014 & 3548 & 49 & 13 & Energy metabolism, glycolysis \\
\hline 1236 & P13929 & ENO3 & Beta-enolase & -1.2 & 0.011 & 12846 & 62 & 22 & Energy metabolism, glycolysis \\
\hline 1448 & P07195 & LDHB & L-lactate dehydrogenase B chain & -1.3 & 0.043 & 2156 & 46 & 11 & Energy metabolism, glycolysis \\
\hline 1229 & P07954-2 & $\mathrm{FH}$ & Fumarate hydratase & -1.4 & 0.010 & 2328 & 44 & 12 & Energy metabolism, Krebs cycle \\
\hline 3215 & P15090 & FABP4 & Fatty acid-binding protein, adipocyte & +1.5 & 0.038 & 4748 & 70 & 10 & Energy metabolism, lipid, ER stress \\
\hline 1007 & P04040 & CAT & Catalase & -1.3 & 0.026 & 654 & 21 & 9 & Detoxification, cytoprotection \\
\hline 1754 & E9PH29 & PRDX3 & Thioredoxin-dependent peroxide reductase, & +1.5 & 0.012 & 1802 & 47 & 9 & Detoxification, cytoprotection \\
\hline
\end{tabular}


Table 2 Differentially expressed muscle proteins in low ionic strength (LIS) extract between adult (56 yr) and old (78 yr) post-menauposal women (Continued)

\begin{tabular}{|c|c|c|c|c|c|c|c|c|c|}
\hline 1858 & Q99497 & PARK7 & Protein DJ-1 & +1.2 & 0.043 & 334 & 42 & 6 & Detoxification, cytoprotection \\
\hline 1107 & P05091 & $\mathrm{ALDH} 2$ & Aldehyde dehydrogenase & +1.2 & 0.012 & 7985 & 48 & 19 & Detoxification, cytoprotection \\
\hline 1351 & P14550 & AKR1A1 & Alcohol dehydrogenase & +1.4 & 0.006 & 1387 & 46 & 13 & Detoxification, cytoprotection \\
\hline 1011 & P30038 & ALDH4A1 & Delta-1-pyrroline-5-carboxylate dehydrogenase & -1.2 & 0.027 & 1219 & 21 & 9 & Amino acid metabolism \\
\hline 1762 & P04792 & HSPB1 & Heat shock protein beta-1 & +1.3 & 0.027 & 1453 & 51 & 7 & Detoxification, cytoprotection \\
\hline 1763 & P04792 & HSPB1 & Heat shock protein beta-1 & +1.3 & 0.029 & 1286 & 51 & 8 & Detoxification, cytoprotection \\
\hline 2356 & E9PR44 & HSPB5 & Alpha-crystallin B chain & +1.5 & 0.038 & 1046 & 39 & 6 & Detoxification, cytoprotection \\
\hline 2364 & 014558 & HSPB6 & Heat shock protein beta- 6 & +1.2 & 0.043 & 597 & 71 & 4 & Detoxification, cytoprotection \\
\hline 755 & P08238 & $\mathrm{HSPC2} / 3$ & Heat shock protein HSP 90-alpha/beta & +1.9 & 0.035 & 3256 & 38 & 12 & Detoxification, cytoprotection \\
\hline 1081 & B3KQT9 & PDIA3 & Protein disulfide-isomerase A3 & +1.4 & 0.012 & 965 & 36 & 15 & Detoxification, cytoprotection \\
\hline 812 & P00918 & CA2 & Carbonic anhydrase 2 & +1.2 & 0.038 & 3352 & 72 & 15 & Detoxification, cytoprotection \\
\hline 1752 & P07451 & CA3 & Carbonic anhydrase 3 & +1.2 & 0.004 & 3663 & 58 & 11 & Detoxification, cytoprotection \\
\hline 1755 & P07451 & CA3 & Carbonic anhydrase 3 & +1.2 & 0.025 & 6098 & 72 & 14 & Detoxification, cytoprotection \\
\hline 1119 & Q13228 & SELENBP1 & Selenium-binding protein 1 & +1.2 & 0.006 & 4100 & 70 & 23 & Detoxification, cytoprotection \\
\hline 1127 & Q13228 & SELENBP1 & Selenium-binding protein 1 & +1.2 & 0.036 & 3543 & 63 & 21 & Detoxification, cytoprotection \\
\hline 3614 & P22314 & UBA1 & Ubiquitin-like modifier-activating enzyme 1 & +1.8 & 0.033 & 7675 & 42 & 29 & Proteolysis \\
\hline 3654 & P55072 & VCP & Transitional endoplasmic reticulum ATPase & +1.5 & 0.011 & 1920 & 39 & 23 & Proteolysis \\
\hline 1088 & P12955 & PEPD & Xaa-Pro dipeptidase & +1.4 & 0.021 & 948 & 24 & 9 & Proteolysis \\
\hline 1014 & P01008 & SERPINC1 & Antithrombin-III & -1.2 & 0.014 & 3612 & 44 & 18 & Proteolysis \\
\hline 1070 & P02774 & GC & Vitamin D-binding protein & -1.4 & 0.008 & 2704 & 40 & 14 & Serum \\
\hline 2892 & P02766 & $T T R$ & Transthyretin & -1.3 & 0.026 & 3695 & 65 & 8 & Serum \\
\hline 1847 & P02647 & APOA1 & Apolipoprotein A-I & -1.5 & 0.002 & 5385 & 55 & 15 & Serum \\
\hline 1855 & P02647 & APOA1 & Apolipoprotein A-I & -1.5 & 0.004 & 8189 & 54 & 15 & Serum \\
\hline 3624 & P02647 & APOA1 & Apolipoprotein A-I & -1.3 & 0.042 & 1347 & 41 & 8 & Serum \\
\hline 681 & P02787 & TF & Serotransferrin & +1.7 & 0.047 & 1523 & 38 & 16 & Serum \\
\hline
\end{tabular}


confirmed by the up-regulation of one isoform of fast troponin T (TNNT3, spot 1123) which is a major regulator of the thin filament. Troponin $\mathrm{T}$ directly interacts with key components in the thin filament regulatory system to mediate the activation and force development of actomyosin contractile units [26]. Age-related changes in fibers expressing various myosin light chain isoforms were previously described for MYL1, MYL2 and TNNT3 $[15,17,20]$; however, these changes were manifested differentially in distinct muscles.

Interestingly, the old skeletal muscle also exhibited altered levels of several fragments of sarcomeric proteins. Thus, there were higher levels of $\mathrm{N}$-terminal (spots 1333 and 1415) and C-terminal (spot 1417) fragments of skeletal $\alpha$-actin (ACTA1), and a higher level of a C-terminal fragment (spot 570) of myosin-1 (MYH1), the type IIX adult fast myosin heavy chain. The old muscle also exhibited lower level of a C-terminal fragment of TTN (LIS-spot 1734), when compared to adult muscle. Such fragments were not observed for non-sarcomeric proteins, and may indicate perturbations in sarcomeric proteolytic pathways.

A feature of human muscle ageing was also the increased expression of ankyrin repeat domain-containing protein 2 (ANKRD2, LIS-spot 1361). ANKRD2 is a member of the mechano-sensing proteins that link myofibrillar stress response to muscle gene expression $[27,28]$. ANKRD2 interacts both with I-band sarcomeric proteins and with nuclear transcription factors [29]. This stretchresponse protein is preferentially expressed in slow type-I fibers, and is induced by denervation, which is consistent with neuronal remodeling in ageing muscle [30].

Aging of skeletal muscle involves a decrease in both total number (hypoplasia) and size (atrophy) of muscle fibers. No consensus has been reached in the literature on whether hypoplasia is associated with a shift in fiber type distribution towards higher [31-33], lower [34,35] or unaltered $[12,36,37]$ percentages of type-I versus type-II fibers. However, previous studies based on myosin heavy chain $(\mathrm{MYH})$ histochemistry agreed that atrophy mostly affects type-II fibers [12,31,32,34,38]. In our 2DGE analyses, there was no clear evidence for a fast-to-slow transition on the unique basis of the differential expression of myosin light chain and troponin isoforms.

\section{Cytoskeletal proteins}

The integrity of muscle fibers depends on cytoskeletal components, which align sarcomeres and anchor them across the sarcolemma to the basement membrane [39]. Two isoforms of vinculin (VCL, LIS-spots 522 and 526) were enhanced during ageing. VCL localizes to adhesion junctions and is a central component of muscle costameres [40,41]. VCL is placed between the integrin-talin complex and the actin cytoskeleton and is a major candidate for transduction of force during the contractile cycle. Besides binding to actin, VCL interacts with signaling networks and is important for signal transduction between the extracellular matrix and the cytoskeleton [42].

Finally, the four and a half LIM domain protein 3 (FHL3, LIS-spot 1418), which is down-regulated in our analysis, is an adaptor protein with numerous interaction partners. In adult fibers, FHL3 interacts with cytoskeletal actin [43] and co-localizes with integrin receptors at the periphery of Z-discs [44]. By binding to integrin and actin, FHL3 might then directly link the cytoskeleton to the extracellular matrix. FHL3 also plays a role in myogenic progenitor cells (satellite cells), where it localizes to the nucleus and has been implicated in the regulation of proliferation [45] and differentiation [46].

VCL and FHL3 have not been previously identified by proteomic surveys of human skeletal muscle ageing $[11,20,21]$. Shot-gun proteomics confirmed the up-regulation of ANKRD2 [23], and Western blotting experiments performed with total muscle extracts confirmed the differential expressions that we observed for VCL and FHL3 in LIS extracts (Figure $3 \mathrm{~A}$ and $\mathrm{B}$ ). In all, the modifications that we report for sarcomeric actomyosin and cytoskeletal proteins are most likely related to disorganization of myofibers in old muscles. Moreover, these changes suggest an influence of the ageing process on the maintenance of the proper organization of sarcolemma in regular structures that are closely linked to costameres, and on the response to extracellular signals. Thus, the age-related changes in sarcomeric and cytoskeletal proteins may result in alterations in contractile properties and contribute to the development of sarcopenia.

\section{Age-related changes in skeletal muscle affect signal transduction}

In skeletal muscle, intracellular calcium $\left(\mathrm{Ca}^{2+}\right)$ is an important secondary messenger for signal transduction and is essential for cellular processes such as excitationcontraction coupling. Action potentials elicit contractions by releasing $\mathrm{Ca}^{2+}$ from the sarcoplasmic reticulum (SR) via the ryanodine receptors (RyRs). RyRs are modulated directly or indirectly by various ions, small molecules and proteins, including calsequestrin. In this study, proteomics analysis of muscle ageing identified an up-regulation of calsequestrin-1 (CASQ1, spot 665), which is a major intra$\mathrm{SR} \mathrm{Ca}^{2+}$ buffer that regulates the activity of RyRs $[47,48]$.

RyR receptors have several potential phosphorylation sites in their cytoplasmic domains and protein kinase A (PKA) has been shown to phosphorylate RyRs. Our analysis shows an increased level of the PKA type I $\alpha$ regulatory subunit (PRKAR1A, LIS-spot 1179) during ageing. Among other substrates PKA can phosphorylate RyR, and PKA-mediated phosphorylation of RyR may result in leaky RyR channels and impaired $\mathrm{Ca}^{2+}$ homeostasis $[49,50]$. 


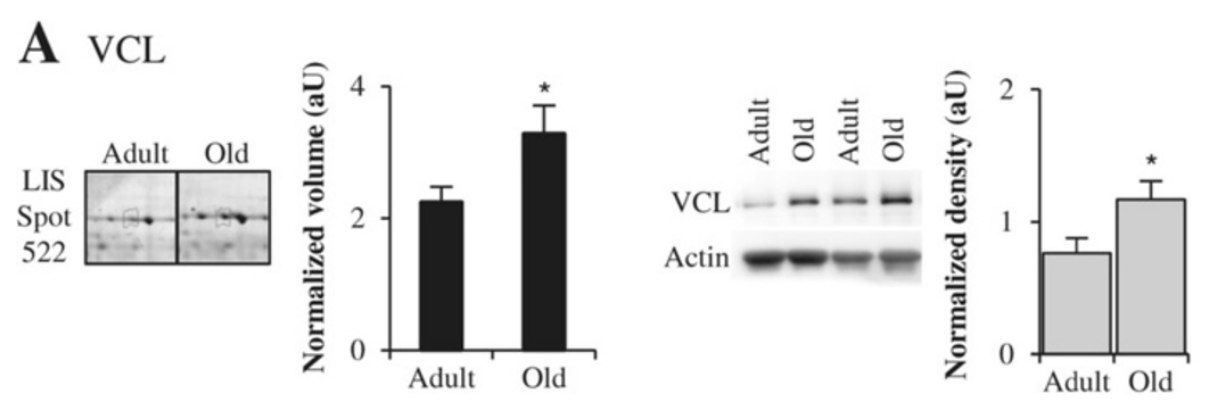

\section{B FHL3}
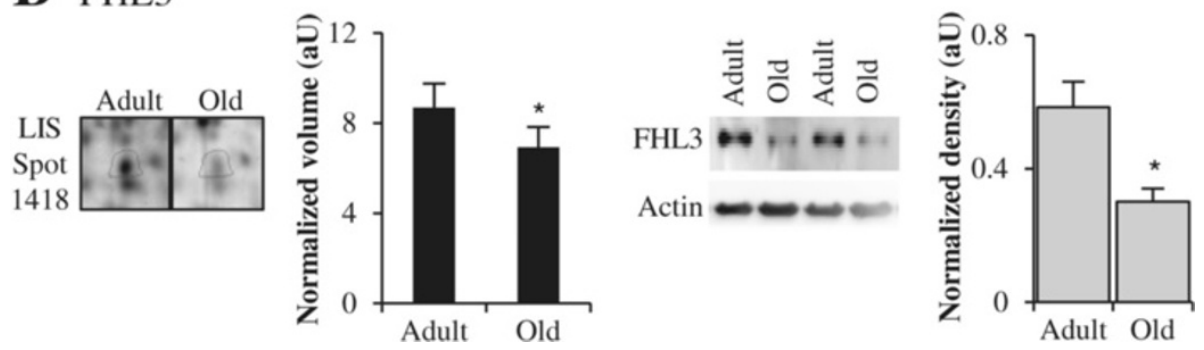

Figure 3 Examples of differential expression of cytoskeletal proteins. Representative sections of 2DGE images (left panel) and representative Western blots (right panel) for vinculin (VCL) (A) and four and a half LIM domains 3 (FHL3) (B). In each panel, histograms represent normalized volume of protein spot $(n=6)$, and Western blot quantification $(n=7)$ for adult and old post-menopausal women. Results are indicated as means \pm SE. * $P<0.05$ indicates significant difference between adult and old women.

After initiation of muscle contraction by increasing cytoplasmic $\mathrm{Ca}^{2+}, \mathrm{Ca}^{2+}$ is pumped back to the SR by sarcoplasmic reticulum $\mathrm{Ca}^{2+}$ ATPase (SERCA) leading to relaxation. Sarcalumenins (SRL) are major luminal glycoproteins that codistribute with SERCA and play a role in $\mathrm{Ca}^{2+}$ transport and sequestration [51,52]. There are two SRL isoforms $(160-\mathrm{kDa}$ and $53-\mathrm{kDa})$ that are generated by alternative splicing [51]. In the present study, the $53-\mathrm{kDa}$ isoform (spot 858 ) was found to be reduced in aged human muscle, and this reduction was confirmed by Western-blotting (Figure 4A). The agerelated decrease of SRL is in agreement with previous studies in rat muscle indicating a shorter half-life of the $53-\mathrm{kDa}$ isoform [53] and a lower level of the $160-\mathrm{kDa}$ isoform [54].

We have also identified an up-regulation of myozenin-1 (MYOZ1, also termed calsarcin-2, spot 3260) which is expressed in fast-twitch fibers of skeletal muscle and modulates the function and substrate specificity of calcineurin, a $\mathrm{Ca}^{2+} /$ calmodulin-dependent serine-threonine phosphatase that plays an important role in transducing calcium-dependent signals [55]. This increase in MYOZ1 was also confirmed by Western-blotting (Figure 4B).

In skeletal muscle, numerous proteins can bind $\mathrm{Ca}^{2+}$, and muscle ageing was further associated with higher level of three members of the annexin family which undergo $\mathrm{Ca}^{2+}$-dependent binding to the cellular membranes. We identified annexin A1 (ANXA1 or lipocortin I, LIS-spot 1494), A5 (ANXA5, LIS-spot 1619) and A7 (ANXA7 or Synexin, spot 758). Annexins have been involved in a broad range of molecular and cellular processes. Noteworthy ANXA1 may contribute to the regeneration of skeletal muscle tissue by modulating migration [56] and fusion [57] of satellite cells. ANXA1 is overexpressed in different muscular dystrophies [58] and can further participate in sarcolemmal and T-tubular repair processes [59]. ANXA5 also promotes membrane repair by selfassembling into two-dimensional arrays on membranes [60]. ANXA7 was originally described as a protein that provokes fusion of lipid vesicules [61]. More recently, ANXA7 was identified as an essential protein for autophagy induction by modulating the intracellular $\mathrm{Ca}^{2+}$ concentration [62]. Western-blotting experiments confirmed the overexpression of ANXA1 and ANXA5 (Figure 4C and D) in total extracts of old muscle, compared to adult muscle.

Glutathione S-transferase omega-1 (GSTO1) is distinguished from the other glutathione S-transferase family members by a different active center amino acid residue, which results in loss of prototypical glutathione conjugating activity [63]. Instead, human GSTO1 is reported to potentiate skeletal muscle ryanodine receptor (RyR1) [64]. The age-related down-regulation of GSTO1 (LIS-spot 1673) was confirmed by Western-Blot (Figure 4E), and 


\section{A SRL}
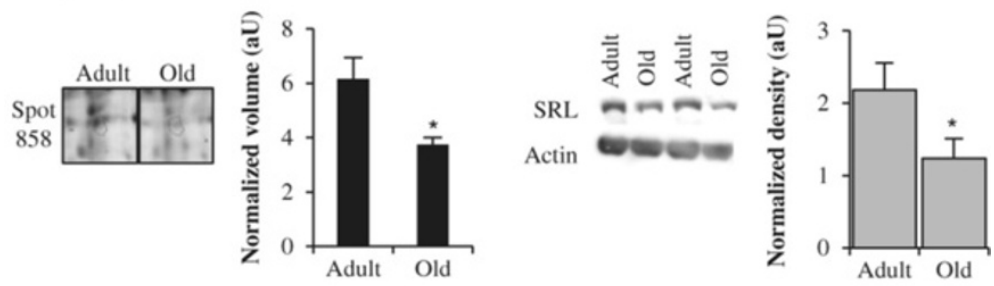

B MYOZ1
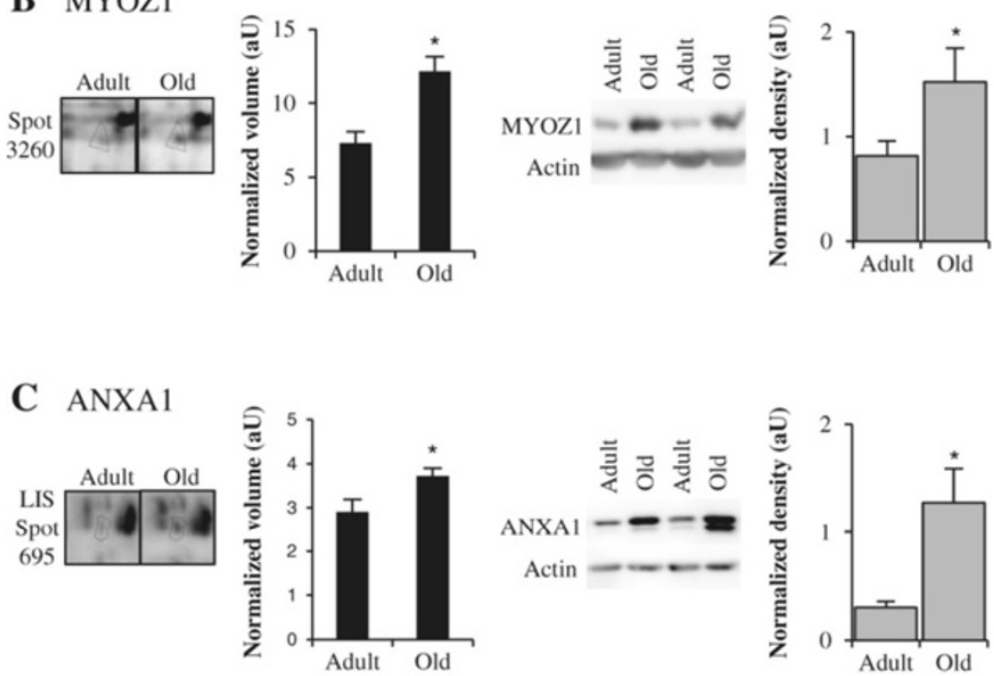

\section{ANXA5}
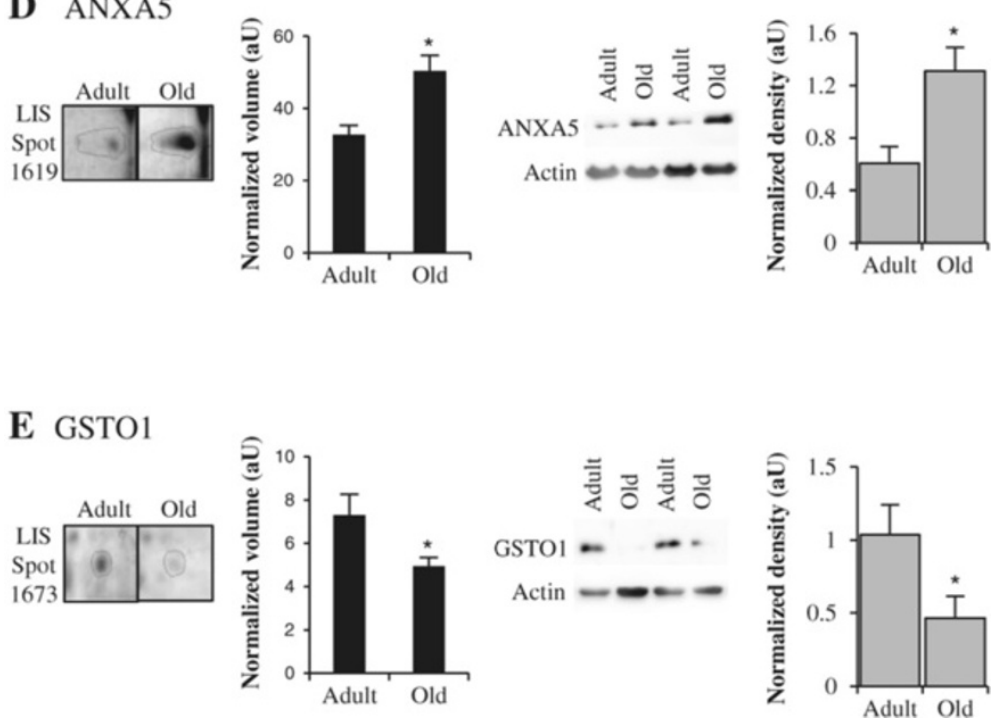

Figure 4 Examples of differential expression of proteins implicated in signal transduction. Representative sections of 2DGE images (left panel) and representative Western blots (right panel) for sarcalumenin (SRL) (A), myozenin-1 (MYOZ1) (B), annexin A1 (ANXA1) (C), annexin A5 (ANXA5) (D) and glutathione S-transferase omega-1 (GSTO1) (E). In each panel, histograms represent normalized volume of protein spot $(n=5-6)$, and Western blot quantification $(n=7)$ for adult and old post-menopausal women. Results are indicated as means $\pm S E$. *: $P<0.05$ indicates significant difference between adult and old women. 
may thereby be involved in the impairment of $\mathrm{Ca}^{2+}$ homeostasis.

Most of these signal transduction proteins (CASQ1, PRKAR1A, MYOZ1, ANXA1 and ANXA7) have never been reported in previous proteomic studies of muscle ageing. Overall, our findings suggest significant alterations in $\mathrm{Ca}^{2+}$ signaling which may be important for the age-related modifications in muscle contractile properties and may contribute to muscle weakness.

\section{Perturbations in the energy metabolism of old muscle}

Disturbance in energy metabolism is another characteristic feature of old muscles. Decreased activities of glycolytic enzymes were previously reported in rat [15] and in human [20] skeletal muscles, whereas expression of mitochondrial enzymes was more controversial in the literature $[11,20]$. Our study points to an age-associated decline in key enzymes of the glycolytic, Krebs cycle and oxidative phosphorylation pathways.

\section{Cytoplasmic energy metabolism}

In the current study, perturbations in the energy metabolism of old muscle were indicated by the down-regulation of five isoforms of monomeric creatine kinase (CKM) (LIS-spots 1261, 1266, 1276, 1289 and 3617). SDS-stable dimeric and trimeric forms of CKM were previously described in mice muscle [65], and we also observed agerelated decreases in dimeric (spots 300 and 332) and trimeric (LIS-spot 516) forms of CKM. Creatine/phosphocreatine is central to maintain energetic homeostasis as it connects intracellular sites of energy demand with sites of ATP production. At these sites, CKM catalyses the transphosphorylation between phosphocreatine and ADP. In sarcomeric M-line, CKM interacts with myomesin and supplies ATP for the actomyosin contractile unit.

The first step of glycogenolysis pathway is the production of glucose-6-phosphate by glycogen phosphorylase (PYGM), which catalyzes the phosphorolytic cleavage of a glucosyl residue from the glycogen polymer. Four isoforms (LIS-spots 289, 659, 676 and 696) of PYGM increased, and one (spot 391) decreased with ageing. The resulting glucose 1-phosphate molecule is converted by phosphoglucomutase to glucose 6-phosphate. Proteomic analysis revealed a decreased expression of phosphoglucomutase-1 (PGM1, LIS-spot 998) in elderly women. Several glycolytic enzymes were also downregulated with ageing. Enolase catalyzes the conversion of 2-phosphoglycerate to phosphoenolpyruvate. In the muscle of post-menopausal women, four isoforms of the muscle specific $\beta$-enolase (ENO3, LIS-spots 1209, 1213, 1215 and 1236) were selectively decreased during ageing. We also detected lower levels of LDHB (LIS-spot 1448) which catalyzes the inter-conversion of pyruvate (the final product of glycolysis) and lactate with concomitant inter- conversion of $\mathrm{NADH}$ and $\mathrm{NAD}^{+}$. Finally, down-regulations of glycerol-3-phosphate dehydrogenase (GPD1, spot 1874) and glycerol-3-phosphate dehydrogenase 1-like protein (GPD1L, spot 3459) were observed. Cytosolic GPD1, together with its mitochondrial isoform, constitute the GPD1 shuttle, which is essential for mitochondrial oxidation of glycolytic NADH. Although less active than its GPD1 counterpart, GPD1L exhibits dehydrogenase activity, and is also implicated in the regulation of hypoxia [66]. Agerelated decline in cytoplasmic glycerol-3-phosphate dehydrogenase may indicate reduced mitochondrial oxidation of cytosolic NADH in old muscle.

Triosephosphate isomerase (TPI1, spot 3511), that catalyzes the isomerization of the dihydroxyacetone phosphate (DHAP) and D-glyceraldehyde 3-phosphate, was the only glycolytic enzyme more abundant in old muscle. TPI1 ensures that DHAP produced by aldolase is further metabolized by the glycolytic enzymes. Impairment of TPI1 can result in chemical conversion of DHAP into toxic methylglyoxal [67] promoting the formation of advanced glycation end-products. In the old muscle, an increased level of TPI1 may then represent a compensatory adaptation to avoid excessive formation of toxic products [68].

\section{Mitochondrial energy metabolism}

Alterations in the mitochondrial Krebs cycle were revealed by the age-dependent reduction in two subunits of the pyruvate dehydrogenase, pyruvate dehydrogenase E1 component subunit $\beta$ (PDHB, spot 1196) and dihydrolipoyl dehydrogenase (DLD, spot 769), and by the reduction in aconitate hydratase (ACO2, spot 577) and FH (LIS-spot 1229), two enzymes that catalyze the isomerization of citrate to isocitrate and the hydration of furamate to malate, respectively. Moreover, alterations in oxidative phosphorylation were also revealed by lower levels of three components of the respiratory chain, $\mathrm{NADH}$ dehydrogenase iron-sulfur protein 2 of complex I (NDUFS2, spot 984), cytochrome b-c1 complex subunit Rieske of complex III (UQCRFS1, spot 3417) and subunit 5A of cytochrome c oxidase of complex IV (COX5A, spot 2713). Ageing was further associated with lower level of ATP synthase subunit $\beta$ (ATP5B, spot 909). Among these proteins implicated in energy metabolism, two (NDUFS2 and UQCRFS1) have never been reported in previous muscle ageing studies, and $\mathrm{FH}$ and ATP5B were similarly found in our shot-gun experiment [23]. Western blotting experiments confirmed alterations in glycolytic and oxidative metabolism, as we observed decreased expression of ENO3, GPD1, NDUFS2 and UQCRFS1, in total extracts of old muscle compared to adult muscle (Figure 5). Concomitant decreases of key enzymes of Krebs cycle and major complexes of oxidative phosphorylation provided evidences for alteration of mitochondrial metabolism in the old skeletal muscle. 

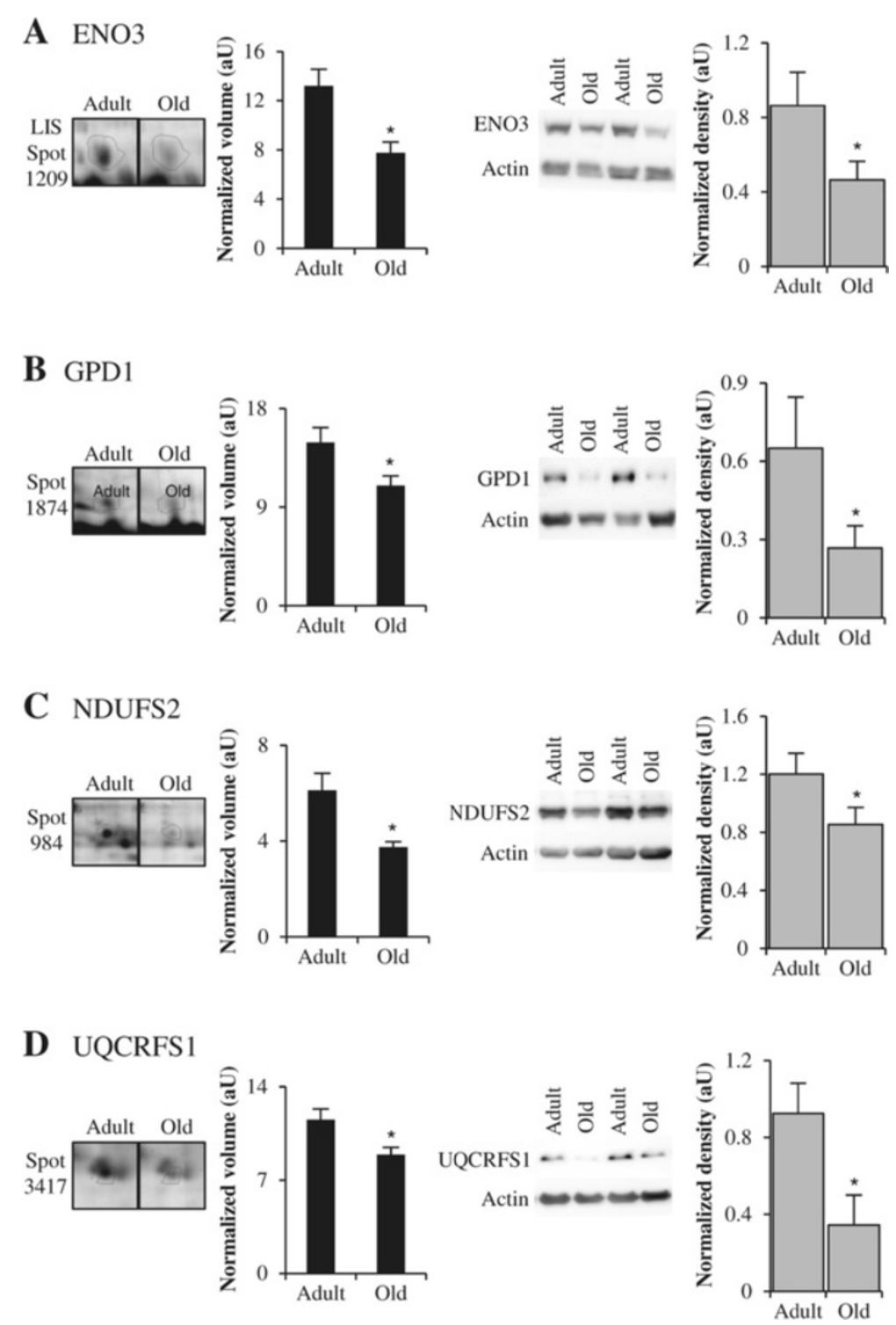

Figure 5 Examples of differential expression of proteins implicated in energy metabolism. Representative sections of 2DGE images (left panel) and representative Western blots (right panel) for $\beta$-enolase (ENO3) (A), glycerol-3-phosphate dehydrogenase [NAD+] (GPD1) (B), NADH dehydrogenase (ubiquinone) Fe-S protein 2 (NDUFS2) (C) and cytochrome b-c1 complex subunit Rieske (UQCRFS1) (D). In each panel, histograms represent normalized volume of protein spot $(n=5-6)$, and Western blot quantification $(n=7)$ for adult and old post-menopausal women. Results are indicated as means $\pm S E$. *: $P<0.05$ indicates significant difference between adult and old women.

\section{Lipid metabolism}

In addition to glucose, lipids are another source of energy in skeletal muscle. Several intracellular fatty acidbinding proteins (FABP) have been identified. They have important functions in the transport of intracellular fatty acids by increasing their solubility and have been shown to enhance the transport of fatty acids from the cell membrane to the site of oxidation, i.e. the mitochondria, and to the site of esterification into intramyocellular triglycerol [69]. Muscle ageing was associated with the down-regulation of heart FABP (FABP3, spot 2371), the major FABP in skeletal muscle, and the up-regulation of adipocyte FABP (FABP4, LIS-spot 3215). FABP3 plays an important, but merely permissive role in fatty acid uptake by skeletal muscles [70]. FABP4 is an adipocyte marker, but is also expressed in muscle fibers [69]. Therefore, the age-related up-regulation of FABP4 may relate to increased number of adipocytes, and/or to an increased expression in muscle fibers. Except in our shot-gun study [23], FABP4 was not noticed in previous reports on sarcopenia. Of note, the lipid chaperone FABP4 (also known as aP2) was also identified as a predominant positive regulator of toxic lipid-induced endoplasmic reticulum (ER) stress [71], and FABP4 up- 
regulation could suggest increased ER stress in old muscle.

Overall, our proteomic analyses therefore provided strong evidences for a decline in both glycolytic and mitochondrial energy metabolism in the old skeletal muscle. Declines in mitochondrial oxidative capacity were previously reported with advancing age [11], although physical activity, rather than chronological age, was also reported to be the primary determinant [72]. Because the activity score was significantly higher for the adult than for the old women group, future studies will be required to specify whether mitochondrial oxidative capacity still decreases in old subjects maintaining physical activity scores.

\section{Detoxification of cytotoxic products and cytoprotection in the old muscle \\ Protection against mitochondrial oxidative stress}

Mitochondrial dysfunctions may lead to an excessive production of reactive oxygen species (ROS), and accumulating evidences suggest that oxidative stress underlies the ageing process in skeletal muscle [14]. The removal of $\mathrm{H}_{2} \mathrm{O}_{2}$ in cells is mediated by catalase (CAT), glutathione peroxidase and peroxiredoxin (PRDX) [73]. In the present study, ageing of human skeletal muscle was associated with lower levels of CAT (LIS-spot 1007) and higher levels of PRDX3 (thioredoxin-dependent peroxide reductase, LIS-spot 1754). Because CAT is localized preferentially in peroxisomes [74], its function is limited to the inactivation of $\mathrm{H}_{2} \mathrm{O}_{2}$ diffusing into these organelles. In contrast, PRDX3 is the only peroxiredoxin restricted to mitochondria, and high levels of PRDX3 may provide a primary line of defence against $\mathrm{H}_{2} \mathrm{O}_{2}$ over-produced by the respiratory chain in old muscle mitochondria. Neither CAT nor PRDX3 have previously been reported in proteomic analyses of muscle ageing.

A wide range of activities have been reported for protein DJ-1 (PARK7, LIS-spot 1858), however, there is consensus that PARK7 is responsive and protective against mitochondrial oxidative stress [75]. PARK7 is an atypical peroxiredoxin-like peroxidase [76]. During oxidative attack, PARK7 is relocalized to mitochondria, has a functional role in scavenging mitochondrial $\mathrm{H}_{2} \mathrm{O}_{2}$ and decreases mitochondrial fragmentation [77]. Therefore elevated levels of PARK7 in the old muscle may be important in regulating cellular antioxidant capacity.

\section{Detoxification of cytotoxic products}

Oxidative stress increases the production of cytotoxic aldehydes, which can react with cellular proteins, nucleic acids and cell membranes. Protection against reactive aldehydes is provided by several families of detoxification enzymes, including aldo-keto reductase (AKR) and aldehyde dehydrogenase (ALDH). Our proteomic analysis provided evidences for perturbed scavenging of reactive aldehyde products in the old muscle, as aldehyde dehydrogenase (ALDH2, LIS-spot 1107) and alcohol dehydrogenase (AKR1A1, LIS-spot 1351), were up-regulated, while aldose reductase (AKR1B1, spot 3328) and delta1-pyrroline-5-carboxylate dehydrogenase (ALDH4A1, LISspot 1011) decreased with ageing. Similar regulations were previously reported during ageing in rat skeletal muscle for ALDH2 [15] and AKR1B1 [16,78]. However, no previous study of muscle ageing has identified the differential expression of AKR1A1 and ALDH4A1.

The mitochondrial enzyme ALDH2 detoxifies aromatic and aliphatic aldehydes (including 4-hydroxy-2-nonenal), which are produced during oxidative stress as a result of lipid peroxidation [79]. The cytosolic oxidoreductase AKR1A1 has broad substrate specificity, and similarly catalyzes the reduction of aliphatic and aromatic aldehydes, ketones, and xenobiotics [80]. The up-regulations of ALDH2 and AKR1A1 thus suggest enhanced scavenging of reactive aldehyde products in the old skeletal muscle. Our Western blot analyses confirmed that muscle ageing is associated with higher levels of ALDH2 (Figure 6A).

While ALDH2 and AKR1A1 act principally as detoxification enzymes, AKR1B1 and ALDH4A1 have additional roles besides that of detoxification. Accumulating evidence attributes a significant role to AKR1B1 in transducing cytotoxic signals initiated by inflammatory cytokines [81]. AKR1B1 inhibitors have been reported to disrupt signalling cascades leading to NFkB activation [82], and reduced levels of AKR1B1 may therefore be important to limit activation of the NFkB pathway in the old muscle.

ALDH4A1 amino acid sequence diverges from the other ALDH [83] and this enzyme is mostly involved in metabolic regulation [84]. ALDH4A1 is metabolically important, since its substrate (glutamic y-semialdehyde) appears as a common intermediate in the degradative and biosynthetic pathways of the amino acids arginine, citrulline, ornithine and proline to and from glutamic acid. The down regulation of ALDH4A1 may thus indicate reduced intermediary metabolism in the old skeletal muscle.

\section{Quality control of cellular proteins}

To detect, refold, and eventually eliminate abnormal proteins, cells use quality control mechanisms that buffer protein homeostasis (proteostasis) against cellular stress. The proteomic analysis described here demonstrated the differential regulation of 9 spots identified as heat shock proteins (HSP). All were increased with ageing and they encompassed 3 HSP groups in human: HSPA, HSPB and HSPC [85].

The small heat shock proteins (HSPB) are ATPindependent chaperones. HSPBs prevent the aggregation of improperly folded or partially denatured proteins, and are involved in their transfer to the ATP-dependent 


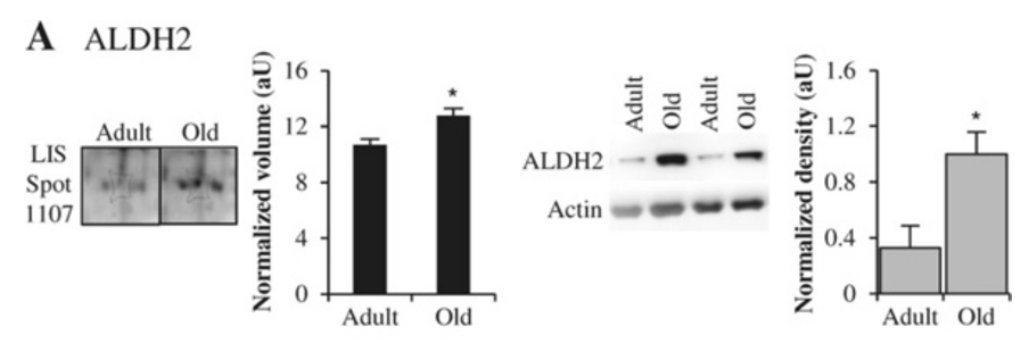

\section{B HSPB5}
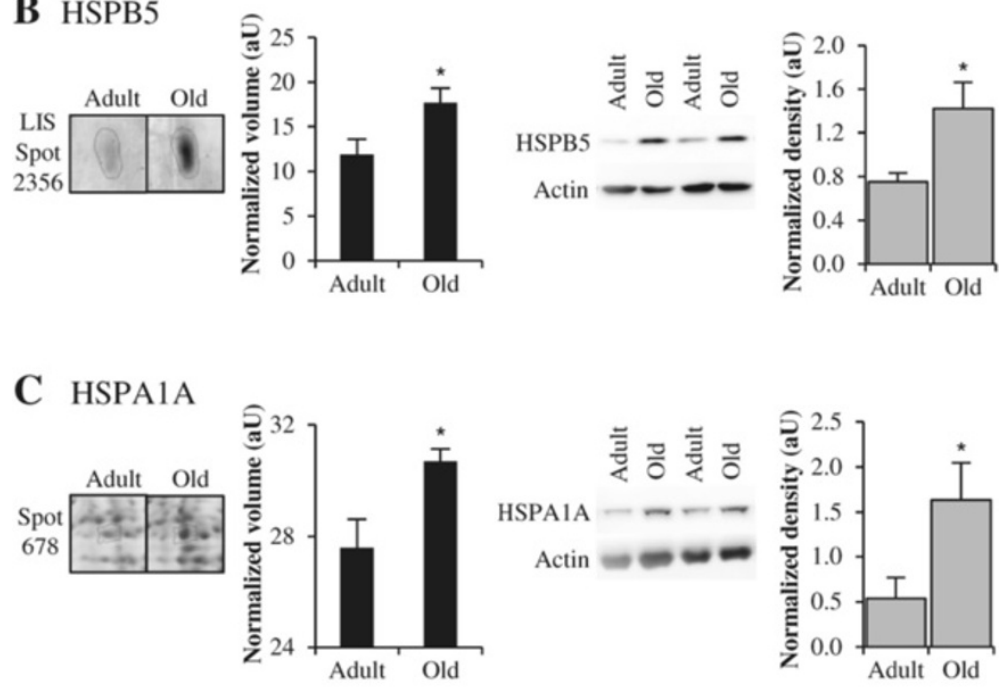

\section{D $\mathrm{HSPC} 3$}
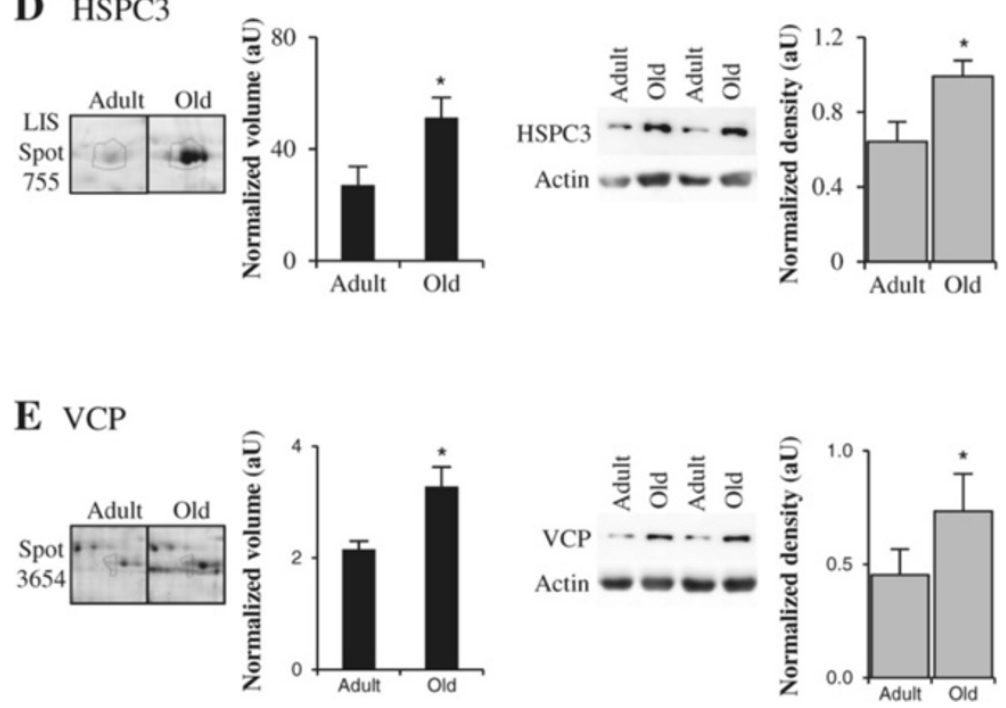

Figure 6 Examples of differential expression of proteins implicated in cytoprotection, cytodetoxification or proteolysis. Representative sections of 2DGE images (left panel) and representative Western blots (right panel) for aldehyde dehydrogenase (ALDH2) (A), a-crystallin B chain (HSPB5) (B), heat shock 70 kDa protein 1A/1B (HSPA1A) (C), HSP 90-beta (HSPC3) (D), and transitional endoplasmic reticulum ATPase (or valosincontaining protein, $\mathrm{VCP})(\mathbf{E})$. In each panel, histograms represent normalized volume of protein spot $(n=5-6)$, and Western blot quantification $(n=7)$ for adult and old post-menopausal women. Results are indicated as means $\pm S E$. *: $P<0.05$ indicates significant difference between adult and old women. 
chaperones or to the protein degradation processes such as proteasomes or autophagosomes [86]. Three HSPBs displayed higher levels in old women compared to adult women: heat shock protein beta-1 (HSPB1 or HSP27, spots 1414 and 2375, and LIS-spots 1762 and 1763), alpha-crystallin B chain (HSPB5 or CRYAB, LIS-spot 2356) and heat shock protein beta-6 (HSPB6 or HSP20, LIS-spot 2364). Similar up-regulation of HSPB1, HSPB5 and HSPB6 have been previously reported for rat muscle ageing $[15,17,78,87]$. Our Western blot experiments performed with total muscle extracts confirmed that the old human muscle exhibited higher levels of HSPB5 than adult muscle (Figure 6B). In addition to chaperone activities, HSPB1 and HSPB5 have the ability to control the redox status, protect the actin cytoskeleton [88] and inhibit apoptotic cell death [89].

The ATP-dependent chaperones of the HSPA group (former HSP70) are essential for proteostasis as they contribute to the folding and assembly of nascent polypeptides, the transport of proteins across membranes, and the selection of misfolded proteins for degradation [90]. Muscle ageing was associated with the up-regulation of two HSPA proteins: the heat shock $70 \mathrm{kDa}$ protein $1 \mathrm{~A} / 1 \mathrm{~B}$ (HSPA1A or HSP70, spot 678), and the mitochondrial stress-70 protein (HSPA9 or GRP75, spot 3332). None of these HSPA have been previously reported in proteomic analyses of muscle ageing, and our Western blot experiments confirmed the age-related up-regulation of HSPA1A (Figure 6C). HSPA1A is the most abundant inducible cytoprotective HSP70 chaperone. Notably in rodents, overexpression of HSPA1A has been repeatedly reported to attenuate muscle atrophy induced by immobilization [91], lengthening contractions [92] or cryo-lesions [93]. It is therefore likely that the old human muscle may increase HSPA1A levels as a protection against muscle atrophy. HSPA9 is a central component of the mitochondrial protein import motor and it plays a key role in the folding of matrix-localized mitochondrial proteins. HSPA9 is the only known mitochondrial Hsp70 chaperone, and thus serves as a unique scavenger of toxic protein aggregates in human mitochondria [94].

One HSPC was further found to be up-regulated in these ageing muscles: the heat shock protein HSP 90 (isoform alpha or beta, LIS-spot 755). HSP 90, which has not been identified in previous muscle ageing studies, is another important chaperone that functions downstream of HSPA in the ATP-dependent folding and conformational regulation of many client proteins, including protein kinases, steroid receptors, endothelial NO synthase and transcription factors [95]. Most of the clients, with which HSP 90 interacts, are thus involved in signal transduction, making HSP 90 a critical factor in cell signalling. Western blot experiments confirmed the agerelated up-regulation of HSP 90-beta (HSPC3, Figure 6D).
Finally and in addition to the HSP proteins, the chaperone operating in the endoplasmic reticulum (ER), protein disulfide-isomerase A3 (PDIA3, LIS-spot 1081), was also found to increase with human muscle ageing, and this observation is in agreement with previous studies in rat $[15,96]$. PDIA3 is a multifunctional protein with thiol-protein disulphide oxidoreductase activity, which ensures proper folding of glycoproteins and assembly of major histocompatibility complex class I complex [97]. Outside the ER, PDIA3 also functions as a plasma membrane receptor for $1 \alpha, 25$-dihydroxy vitamin D3 [98], which might be important with regard to the implication of Vitamin D in ageing [99].

\section{Cytoprotection in the old skeletal muscle}

In agreement with a previous study in rat [78], higher levels of two isoforms of carbonic anhydrase 2 (CA2, spot 3289 and LIS-spot 812) were identified in senescent human muscle. No consensus has been reached in the literature about CA3, as both increased [16,21] and decreased levels [11,17] were observed in old muscles. Our analyses of muscle ageing in women indicated an overexpression of 2 isoforms of CA3 (LIS-spots 1752 and 1755) and this was confirmed by our shot-gun study [23]. The various isoforms of CAs play a crucial role in $\mathrm{CO}_{2}$-removal and $\mathrm{CO}_{2}$-provision for metabolic processes, and are central for the acid-base balance and the regulatory processes of ion homeostasis. Numerous proteins are involved in ion homeostasis, including the selenium-binding protein 1 (SELENBP1) of which two isoforms were increased (LIS-spots 1119 and 1127) and one isoform was decreased (spot 877) in ageing.

\section{Proteolytic systems}

Muscle proteins are continuously turning over, and cells contain multiple proteolytic systems to carry out the degradation process. Several components of the major proteolytic systems, i.e. ubiquitin-proteasome [100] and lysosomal autophagy $[101,102]$, were in the present study differentially regulated with ageing in human skeletal muscle. The old muscle thus exhibited higher levels of the ubiquitinlike modifier activating enzyme 1 (UBA1, LIS-spot 3614), and transitional endoplasmic reticulum ATPase (or valosin-containing protein, VCP, LIS-spot 3654), while the proteasome subunit beta type-4 (PSMB4, spot 2410), UV excision repair protein RAD23 homolog A (RAD23A, spot 3387) and mitochondrial elongation factor $\mathrm{Tu}$ (TUFM, spot 3270) were down-regulated during ageing.

The VCP ATPase binds multiple ubiquitin ligases and ubiquitinated proteins and triggers extraction of client proteins from complexes or cellular surfaces, often to facilitate degradation by the proteasome [103]. VCP is thus central for the extraction and degradation of misfolded endoplasmic reticulum-associated (ERAD) [104] 
and mitochondrial membrane proteins [105]. VCP is also involved in a wide variety of cellular processes, such as DNA repair [106], myofibril biogenesis [107], membrane fusion [108], autophagosome maturation [109] and mitophagy [110]. The up-regulation of VCP in skeletal muscle of old women was confirmed by Western-blot analysis (Figure 6E), and is in agreement with previous observations in rat muscle [111]. The scaffold protein RAD23A, which was originally identified as an important factor involved in the recognition of DNA lesions [112], also serves as an ubiquitin receptor and plays a central role in targeting polyubiquitynated proteins, including ERAD substrates, for proteasomal degradation [113]. TUFM is important to deliver aminoacyl-tRNA to mitochondrial ribosome, and also promotes autophagy by interacting with autophagy-related proteins ATG12-ATG5 and ATG16L1 [114].

In addition to intracellular proteolysis, proteomics analysis of muscle ageing identified an up-regulation of the Xaa-Pro dipeptidase (PEPD, LIS-spot 1088), an extracellular proteinase which specifically splits iminodipeptides with C-terminal proline or hydroxyproline. Because of the high level of iminoacids in collagen, PEPD seems to be important for extracellular matrix remodeling [115]. At the extracellular level, we also found that muscle ageing was associated with lower level of anti-thrombin III (SERPINC1, LIS-spot 1014), which belongs to the family of serine protease inhibitors.

With the exception of VCP [111], none of these potential proteolysis biomarkers has previously been mentioned in any proteomic study on muscle ageing.

\section{Serum and transport proteins}

Several spots were identified as differentially expressed plasma transport proteins. A number of these proteins were found decreased in aged muscle, including vitamin D binding protein (GC, LIS-spot 1070), transthyretin (TTR, LIS-spot 2892) and apolipoprotein A-I (APOA1, LIS-spots 1847, 1855 and 3624). Vitamin D binding protein is a major plasma transport protein for vitamin $\mathrm{D}$, while TTR transports thyroxine (T4) and retinol (vitamin A) through the association with retinol-binding protein. As a major component of the high density lipoprotein complex, APOA1 helps to clear fats, including cholesterol, from peripheral tissues. APOA1 is also partly localized on skeletal muscle lipid droplets [116]. In contrast, serotransferrin (TF, LIS-spot 681), which controls level of iron and oxidative stress by increasing iron uptake, was up-regulated in aged muscle. Another serum protein, fibrinogen gamma chain (FGG, spot 919), was decreased during ageing. Altered levels of serum proteins may be related to impaired blood-flow distribution that has been reported in aged muscle fibers [117].

\section{Miscellaneous}

Two isoforms of the ES1 protein homolog (C21orf33, spots 1429,1430 ) also decreased in aged muscle. C21orf33 (also known as KNP1) is ubiquitously expressed but strongly so in heart and skeletal muscle and potential mitochondrial targeting signals were found in this protein [118], but its actual physiologic function is not known. Cytosolic 5'-nucleotidase 3 (NT5C3A, spot 1177) mainly catalyzes the dephosphorylation of pyrimidine nucleoside monophosphates, and therefore plays an important role in both endogenous nucleoside and nucleotide pool balance [119]. The age-related down-regulation of NT5C3A (-1.6 fold) that we observed in senescent women has not been previously reported in the literature. Finally, spot 1429 decreased 1.2-fold and is identified as apolipoprotein B mRNA-editing enzyme, catalytic polypeptide-like 2 (APOBEC2) that belongs to the cytidine deaminase superfamily and mediates editing of mRNA. Interestingly, APOBEC2 deficiency in mice has recently been associated with a shift to a slow-fiber type in muscle, and with diminished body mass and mild myopathy [120].

\section{Conclusions}

To conclude, our proteomics analyses has resulted in the identification of numerous proteins whose expression is dysregulated in old skeletal muscle. To our knowledge, this is the most extensive proteomic study of muscle ageing in humans. All these proteins have been classified into seven major groups, associated with myofilaments and cytoskeleton, energy metabolism, detoxification, cytoprotection, signal transduction, proteostasis and proteolysis, and Figure 7 summarizes the functional interaction networks linking the differentially expressed proteins. Many of the candidate proteins identified in this study by differential proteomics were previously unrecognized (34 out of 67) in previous ageing studies of skeletal muscle, in particular for proteins implicated in cytoprotection, signal transduction or proteolysis. By comparing adult and old post-menopausal women, we have identified a group of proteins in old skeletal muscle, which indicates potential mechanisms of ageing and may lead to the development of new biomarkers of sarcopenia and novel targets for therapeutic intervention.

\section{Methods}

\section{Subjects}

Subjects were admitted to the Leiden University Medical Center (Leiden, The Netherlands) and Rijnland Hospital (Leiderdorp, The Netherlands) between June 2010 and September 2012. Exclusion criteria consisted of previous knee or hip surgery (with the exception of arthroscopy), rheumatoid disease, diabetes mellitus, use of oral corticosteroids, and metastasized malignancy. Twenty four post-menopausal women undergoing elective hip surgery 


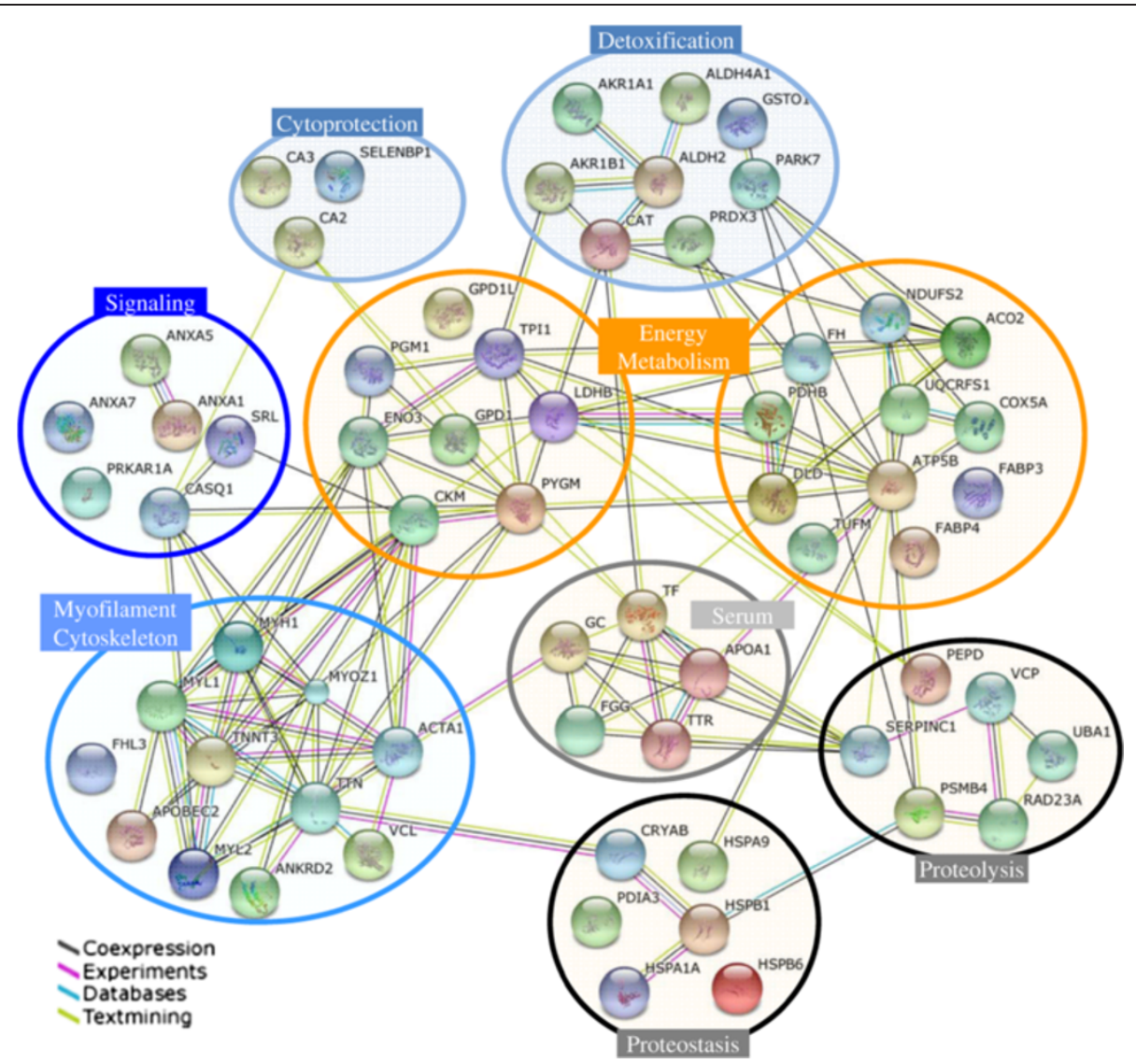

Figure 7 STRING interaction network showing the association between differentially expressed proteins in old post-menopausal women compared to adult women. The interaction map was generated using STRING [123] and default settings (Medium confidence of 0.4 and 4 criteria for linkage: co-expression, experimental evidences, existing databases and text mining). The proteins names used in this network are listed in Tables 1 and 2.

for hip arthrosis were selected in the present study and divided in two groups: adult women aged $56.4 \pm 1.3$ years $(n=11$; age range $48-61$ years $)$ and old women aged $78.3 \pm 0.5$ years $(n=13$; age range $76-82$ years). We limited our study to post-menopausal women in order to avoid potential side effects of the menstrual hormone cycle. The study was approved by the medical ethical committees (P10.060 - HEALTH-2007-2.4.5-10: Understanding and combating age related muscle weakness "MYOAGE") of the Leiden University Medical Center and Rijnland Hospital, and was performed in accordance with the principles of the revised Declaration of Helsinki. Written informed consent was obtained from all patients. The adult subjects were more active than elderly, but not involved in any specific training program. The activity score, based on self-report in a questionnaire, was significantly higher for adult than for old women $(P<0.035)$. Adult women were cycling more than old women $(83 \%$ and $36 \%$, respectively), and adult women used less walking aid than old women (33\% vs. $71 \%)$. The adult and old groups presented similar body weight $(69.0+12.9 \mathrm{~kg}$ and $75.5+$
$12.5 \mathrm{~kg}$, respectively), height $(168+8 \mathrm{~cm}$ and $166+7 \mathrm{~cm}$, respectively) and body mass index. Muscle samples were obtained by surgical biopsy from the vastus lateralis muscle and were immediately frozen in liquid nitrogen and stored at $-80^{\circ} \mathrm{C}$ until used.

\section{Reagents}

Acrylamide, bisacrylamide and Hybond ${ }^{\mathrm{Tw}}-\mathrm{P}$ membrane were purchased from Amersham Bioscience/GE Healthcare (Little Chalfont, UK). IPG buffers, $18 \mathrm{~cm}$ ReadyStrip IPG strips ( $\mathrm{pH} 5-8$ ), $18 \mathrm{~cm}$ ReadyStrip IPG strips ( $\mathrm{pH}$ 3.0-5.6), $18 \mathrm{~cm}$ ReadyStrip IPG strips (pH 5.3-6.5), and Electrode Wicks were from Bio-Rad Laboratories (Marnes la Coquette, France), and orthophosphoric acid, ammonium sulphate and absolute ethanol were from VWR (Strasbourg, France). All other chemicals were from Sigma (L'Isle-d'Abeau Chesnes, France). Sequence grade-modified trypsin was purchased from Promega (Charbonnières-lesbains, France), and Luminata ${ }^{\text {mo }}$ Western Horseradish peroxidase (HRP) substrate and ReBlot Plus Strong antibody stripping solution were from Millipore (Molsheim, France). 
For immunoblotting, the monoclonal antibodies against VCL and FHL3 were from Sigma. The anti-mouse IgGHRP, anti-rabbit IgG-HRP, anti-SRL and anti- $\beta$-actin (ACTB) were from Santa-Cruz biotechnology (Heidelberg, Germany). The polyclonal antibodies against GPD1, MYOZ1, ANXA1, ANXA5, GSTO1, HSPB5, HSPC3, ALDH2, NDUFS2, UQCRFS1, ENO3, HSPA1A and VCP were purchased from Euromedex (Genetex, Souffelweyersheim, France).

\section{Protein extraction}

Total muscle extracts and LIS extracts were prepared for each subject, and each individual was assessed separately. For total muscle extracts, biopsies of vastus lateralis muscle were from twelve post-menopausal women divided in two groups: adult control $(n=5)$ and aged $(n=7)$. Muscle aliquots were homogenized $(40 \mathrm{mg} / \mathrm{ml})$ in a solubilisation buffer containing 8.3 M urea, $2 \mathrm{M}$ thiourea, 2\% (w/v) CHAPS, 1\% (v/v) dithiothreitol, and 2\% (v/v) IPG buffer pH 3-10 using a TissueRuptor (Qiagen, Courtaboeuf, France), shaken for $30 \mathrm{~min}$ on ice and centrifuged for 30 $\min$ at $10,000 \mathrm{X} g$. The supernatants were aliquoted and stored at $-20^{\circ} \mathrm{C}$ until analysis. Protein concentration, determined using the Bradford assay system (Bio-Rad), was $7.2 \pm 1.1 \mathrm{mg} / \mathrm{ml}$ and $5.5 \pm 1.2 \mathrm{mg} / \mathrm{ml}$ for the adult and old group, respectively.

LIS extracts were prepared from muscle biopsies of twelve post-menopausal women, either adult $(n=6)$ or aged $(n=6)$, according to Sayd et al. [121]. Briefly, frozen muscle was homogenized using a TissueRuptor in $40 \mathrm{mM}$ Tris (pH 7.0), 2 mM EDTA, and protease inhibitor cocktail (Sigma). After centrifugation at $4^{\circ} \mathrm{C}$ for 10 $\min$ at $10,000 \mathrm{X} g$, the supernatant, referred to as LIS extract, was stored at $-80^{\circ} \mathrm{C}$. Protein concentration was $9.3 \pm 2.2 \mathrm{mg} / \mathrm{ml}$ and $9.4 \pm 1.6 \mathrm{mg} / \mathrm{ml}$ for the adult and old group, respectively.

\section{Two-dimensional gel electrophoresis}

For total muscle extracts, $700 \mu \mathrm{g}$ protein were separated per gel using IPG strips of three different $\mathrm{pH}$ ranges $(\mathrm{pH}$ 3.0-5.6, pH 5.3-6.5 and $\mathrm{pH}$ 5-8) for each individual. For isoelectrofocusing, samples were diluted with rehydration buffer containing 8.3 M urea, $1 \mathrm{M}$ thiourea, 2\% (w/v) CHAPS, 0.28\% (v/v) dithiothreitol, 2\% (v/v) IPG buffer (pH 3-10), and 0.01\% (w/v) Coomassie Brilliant blue $\mathrm{R}-250$. The IPG strips were passively rehydrated with $330 \mu \mathrm{l}$ of this solution for $16 \mathrm{~h}$ under mineral oil in the PROTEAN IEF Cell system (Bio-Rad) at $20^{\circ} \mathrm{C}$, and actively rehydrated using Electrode Wicks loaded onto IPG strips for $6 \mathrm{~h}$ at $50 \mathrm{~V}$. During active rehydration, Electrode Wicks were changed every $2 \mathrm{~h}$. Isolectrofocusing was then performed at $0.05 \mathrm{~mA}$ per IPG strip at $50 \mathrm{~V}$ for $2 \mathrm{~h}, 200 \mathrm{~V}$ for $1 \mathrm{~h}, 500 \mathrm{~V}$ for $1 \mathrm{~h}, 1000 \mathrm{~V}$ for $2 \mathrm{~h}, 8000 \mathrm{~V}$ for $6 \mathrm{~h}$ and finally $8000 \mathrm{~V}$ to achieve 46,000 Vh.
For LIS extracts, gels were made in triplicate for each individual and $700 \mu \mathrm{g}$ protein was analyzed per gel. The IPG strips ( $\mathrm{pH}$ 5-8) were passively and actively rehydrated as described above and isolectrofocusing was performed at $0.05 \mathrm{~mA}$ per IPG strip at $50 \mathrm{~V}$ for $1 \mathrm{~h}, 250 \mathrm{~V}$ for $1 \mathrm{~h}, 500 \mathrm{~V}$ for $1 \mathrm{~h}, 1000 \mathrm{~V}$ for $2 \mathrm{~h}, 1000 \mathrm{~V}$ for $1 \mathrm{~h}$, $8000 \mathrm{~V}$ for $7 \mathrm{~h}$ and finally $8000 \mathrm{~V}$ to achieve 60,000 Vh.

The strips were then equilibrated twice for $15 \mathrm{~min}$ with gentle shaking in equilibration buffer containing 6 $\mathrm{M}$ urea, $50 \mathrm{mM}$ Tris-HCl buffer $(\mathrm{pH} 8.8), 30 \%$ (v/v) glycerol, $2 \%(\mathrm{w} / \mathrm{v})$ SDS. DTT $(1 \% \mathrm{w} / \mathrm{v})$ was added to the first, and iodoacetamide $(5 \% \mathrm{w} / \mathrm{v})$ to the second equilibration buffer. Separation of proteins, according to molecular weight, was carried out using a Protean Plus DodecaCell system (Bio-Rad) on homogenous $20 \mathrm{~cm}$ polyacrylamide gels $(11 \% \mathrm{~T}, 2.6 \% \mathrm{C})$. The equilibrated strips were sealed to the top of the horizontal gel with agarose and subjected to $50 \mathrm{~V}$ for $1 \mathrm{~h}$ followed by $9 \mathrm{~mA}$ per gel until the blue dye reached the bottom of the gel.

\section{Visualization of proteins and image analysis}

2DGE were fixed overnight in a solution containing 30\% (v/v) ethanol and $2 \%(\mathrm{v} / \mathrm{v})$ orthophosphoric acid, washed twice for $30 \mathrm{~min}$ in $2 \%(\mathrm{v} / \mathrm{v})$ orthophosphoric acid and then transferred to a solution containing $18 \%(\mathrm{v} / \mathrm{v})$ ethanol, 2\% (v/v) orthophosphoric acid and 15\% (v/v) ammonium sulphate for $30 \mathrm{~min}$. The gels were stained for $72 \mathrm{~h}$ with $0.06 \%(\mathrm{w} / \mathrm{v})$ Coomassie Blue G-250 added to this last solution. Gels were scanned using the ImageScanner and LabScan-v.5 software (Amersham Bioscience) and protein spots were analyzed and matched between all gels using Progenesis SameSpot software (Non Linear Dynamics, Newcastle upon Tyne, UK). Age effect was evaluated for normalized volumes of 2DGE spots using an unpaired Student's $t$ test procedure with significance set at $P<0.05$. The numbers of biological replicates (5-7) that we used in the present study is similar to those used in previous investigations [20,21]. Throughout the manuscript, we qualified the differential spots as "potential" biomarkers, being aware that any list of candidate identified in a discovery stage must be validated in other large and independent cohort of subjects.

\section{Protein identification by mass spectrometry}

Proteins with significant changed abundance were picked for tryptic digestion from gels. Excised protein spots from 2DGE were destained with $25 \mathrm{mM}$ ammonium bicarbonate, $5 \%(\mathrm{v} / \mathrm{v})$ acetonitrile for $30 \mathrm{~min}$ and twice in $25 \mathrm{mM}$ ammonium bicarbonate, $50 \%(\mathrm{v} / \mathrm{v})$ acetonitrile for $30 \mathrm{~min}$ each. Protein spots were then dehydrated using 100\% acetonitrile for $10 \mathrm{~min}$ and dried in a vacuum SpeedVac. Proteins were digested overnight at $37^{\circ} \mathrm{C}$ using $12.5 \mathrm{ng} / \mu \mathrm{l}$ of sequence grade-modified trypsin (Promega) in $25 \mathrm{mM}$ ammonium bicarbonate. Peptide extraction was optimised 
by adding $100 \%$ acetonitrile, followed by $15 \mathrm{~min}$ of sonication.

After concentration in the SpeedVac, the peptides mixtures were analyzed by nano-LC-MS/MS using an Ultimate 3000 system (Dionex, Voisins le Bretonneux, France) coupled to an LTQ-Velos mass spectrometer (Thermo Fisher Scientific, Bremen, Germany). Eight microliters of each peptide sample were loaded on a $\mathrm{C} 18$ pre-column (300- $\mu \mathrm{m}$ inner diameter $\times 5 \mathrm{~mm}$; Dionex) at $20 \mu \mathrm{l} / \mathrm{min}$ in $5 \%$ acetonitrile, $0.05 \%$ trifluoroacetic acid. After 6 min of desalting, the pre-column was switched on line with the analytical C18 column $(75-\mu \mathrm{m}$ inner diameter $\times 15 \mathrm{~cm}$; PepMap C18, Dionex) equilibrated in $96 \%$ solvent A $(0.5 \%$ formic acid) and $4 \%$ solvent B (80\% acetonitrile, $0.5 \%$ formic acid). Peptides were eluted using a 4-50\% gradient of solvent B during $30 \mathrm{~min}$ at a $300 \mathrm{nl} / \mathrm{min}$ flow rate. The eluate was electrosprayed into the mass spectrometer through a nano-electrospray ion source. The LTQ-Velos was operated in a CID top 10 mode ( 1 full scan MS and the 10 major peaks in the full scan are selected for MS/MS). The Mascot Daemon software (version 2.3.2; Matrix Science, London, UK) was used to perform database searches, using the Thermo Proteome Discoverer v1.3 with default parameters to generate peak lists.

For protein identification, the UniP Human database (2012/11, 86675 seq) was used. Peptide mass tolerance was set to $1.5 \mathrm{Da}$ and fragment mass tolerance was set to $0.8 \mathrm{Da}$. Two missed cleavages were allowed, and variable modifications were methionine oxidation and carbamidomethylation of cysteine. Identification results were imported and filtered by Proteome Discoverer. Protein identification was validated when at least three unique peptides originating from one protein showed significant identification Mascot scores $(P<0.05)$ with False Discovery Rate $(\mathrm{FDR}<5 \%)$ automatically calculated by Proteome Discoverer. When redundancy occurs, Proteome Discover uses principles of parsimony to give unambiguous identification of an isoform of a protein. This was not possible for only 2 spots (LIS spots 1210 and 755), for which we indicate the two isoforms in Table 2. In the present study we considered that proteins validated for the entire number of spots analysed were really present on the basis of Mascot score, percentage of sequence coverage of the entire protein, peptide spectrum matches, unique peptides related to each protein isoform/member, and MW agreements. The mass spectrometry proteomics data have been deposited to the ProteomeXchange Consortium [122] via the PRIDE partner repository with the dataset identifier PXD001527.

\section{Immunoblotting}

For Western-Blot analysis, total protein extracts were resolved by sodium dodecyl sulfate polyacrylamide gel electrophoresis, electrotransferred to Hybon ${ }^{\text {tw }}-\mathrm{P}$ membrane and probed with anti-VCL, anti-FHL3, anti-SRL, anti-MYOZ1, anti-ANXA1, anti-ANXA5, anti-GSTO1, anti-ENO3, antiGPD1, anti-UQCRFS1, anti-NDUFS2, anti-ALDH2, antiHSPB5, anti-HSPA1A, anti-HSPC3, or anti-VCP. Primary antibodies were resolved with corresponding horseradish peroxidase-linked goat anti-mouse or anti-rabbit secondary antibodies, and immunoreactive proteins were detected using enhanced chemiluminescence and a Charge Coupled Device camera (GBOX, Syngene, Cambridge, UK). Each blot was dehybridized using $1 \mathrm{X}$ ReBlot Plus Strong antibody stripping solution and probed with antiACTB for normalization. To determine the significance of ageing, a Student's $t$ test was used with significance set at $P<0.05$; results are expressed as the mean \pm standard deviation.

\section{Functional correlation and pathway analysis}

Pathway analysis was performed using the Search Tool for the Retrieval of INteracting Genes (String) 9.0 database (http://string-db.org) [123]. String analysis options were based on 'evidence' mode, we did not add or remove any protein partners, and we used clustering by $\mathrm{K}$ means to reveal sub-grouping within the network.

\section{Abbreviations}

2DGE: Two-dimensional gel electrophoresis; ACO2: Aconitate hydratase; ACTA1: Skeletal a-actin; ACTB: $\beta$-actin; AKR: Aldo-keto reductase; AKR1A1: Alcohol dehydrogenase; AKR1B1: Aldose reductase; ALDH2: Aldehyde dehydrogenase; ALDH4A1: Delta-1-pyrroline-5-carboxylate dehydrogenase; ANKRD2: Ankyrin repeat domain-containing protein 2; ANXA1: Annexin A1; ANXA5: Annexin A5; ANXA7: Annexin A7; APOA1: Apolipoprotein A-l; APOBEC2: Apolipoprotein B mRNA-editing enzyme, catalytic polypeptide-like 2; ATG: autophagy-related protein; ATP5B: ATP synthase subunit $\beta$; C21orf33: ES1 protein homolog; CA: Carbonic anhydrase; CAP2: Adenylyl cyclase-associated protein 2; CAPNS1: Calpain small 1 regulatory subunit; CASQ1: Calsequestrin-1; CAT: Catalase; CKM: Creatine kinase; COX5A: Subunit 5A of cytochrome c oxidase; DHAP: Dihydroxyacetone phosphate; DLD: Dihydrolipoyl dehydrogenase; ENO3: Beta-enolase; ER: Endoplasmic reticulum; ERAD: Endoplasmic reticulumassociated; FABP: Fatty acid binding protein; FGG: Fibrinogen gamma chain;

FH: Furamate hydratase; FHL3: Four and a half LIM domains protein 3; GC: Vitamin D binding protein; GPD1: Glycerol-3-phosphate dehydrogenase [NAD+]; GPD1L: Glycerol-3-phosphate dehydrogenase 1-like protein; GSTO1: Glutathione S-transferase omega-1; HRP: Horseradish peroxidase; HSP: Heat shock protein; HSPA1A: Heat shock 70 kDa protein 1A/1B; HSPA9: Mitochondrial stress-70 protein; HSPB1: Heat shock protein beta-1; HSPB5: a-crystallin B chain; HSPB6: Heat shock protein beta-6; HSPC3: Heat shock protein HSP 90-beta; LDHB: L-lactate dehydrogenase $\beta$; LIS: Low ionic strength; MYH: Myosin heavy chain; MYH1: Myosin-1; MYL1: Myosin light chain 1/3 skeletal muscle isoform; MYL2: Myosin regulatory light chain 2 ventricular/cardiac muscle isoform; MYOZ1: Myozenin 1; NDUFS2: NADH dehydrogenase (ubiquinone) Fe-S protein 2; NT5C3A: Cytosolic 5'-nucleotidase 3; PARK7: Parkinson disease 7, autosomal recessive early-onset; PDHB: Pyruvate dehydrogenase E1 component subunit $\beta$; PDIA3: Protein disulfide-isomerase A3; PEPD: Xaa-Pro dipeptidase;

PGM1: Phosphoglucomutase-1; PKA: Protein kinase A; PRDX: Peroxiredoxin; PRDX3: Thioredoxin-dependent peroxide reductase; PRKAR1A: CAMP-dependent protein kinase type l-alpha regulatory subunit; PSMB4: Proteasome subunit beta type-4; PYGM: Glycogen phosphorylase; RAD23A: UV excision repair protein RAD23 homolog A; ROS: Reactive oxygen species; RyR: Ryanodine receptor; SELENBP1: Selenium-binding protein 1; SERCA: Sarcoplasmic reticulum $\mathrm{Ca}^{2+}$ ATPase; SERPINC1: Anti-thrombin III; SR: Sarcoplasmic reticulum; SRL: Sarcalumenin; TF: serotransferrin; TNNT3: Fast troponin T; TPI1: Triosephosphate isomerase; TTN: Titin; TTR: Transthyretin; TUFM: Mitochondrial elongation factor Tu; UBA1: Ubiquitin-like modifier activating enzyme 1; UQCRFS1: Cytochrome b-c1 complex subunit Rieske; VCL: Vinculin; VCP: Valosin-containing protein. 


\section{Competing interests}

The authors declare that they have no competing interests.

\section{Authors' contributions}

$M G, B F, A B M, G B B$ and $D B$ conceived the project. MG, CCG and DB designed the experiments. MG, CCG, OG and CC performed the experiments. $L C, C P$, DT and DA contributed reagents. MG, CCG, CC and DB analyzed the data and prepared the Figures. MG and DB drafted the manuscript. All authors edited, revised and approved the final version of the manuscript.

\section{Acknowledgements}

This work was partly funded by the European Union Collaborative Project MyoAge (EC Fp7 CT-223576) and by the Fondation Caisse d'Epargne Rhone-Alpes (CERA Sarcopenie $n^{\circ} 30$ ). MG was supported by a postgraduate fellowship from Région Auvergne and Fonds Européens de Développement Régional (FEDER, $\left.n^{\circ} 23000422\right)$, and LT by a postdoctoral fellowship from Région Auvergne and FEDER (n³5380 T2a 2011 Prenusa). The authors wish to gratefully acknowledge Professor Philippe Courpron for his constant support and his central role in initiating and developing this work. The authors thank the Fondation pour I'Université de Lyon for assistance with obtaining reagents.

\section{Author details}

${ }^{1}$ INRA, UMR 1019, Centre de Recherche en Nutrition Humaine, Université d'Auvergne, F-63122 Saint Genès Champanelle, France. ${ }^{2}$ Clermont Université, Université d'Auvergne, F-63000 Clermont-Ferrand, France. ${ }^{3}$ INRA, Plateforme d'Exploration du Métabolisme, Composante Protéique, F-63122 Saint Genès Champanelle, France. ${ }^{4}$ Sorbonne Universités, UPMC Université Paris 06, UMR 8256, Biological Adaptation and Ageing - IBPS, CNRS-UMR 8256, INSERM U1164, F-75005 Paris, France. ${ }^{5}$ Department of Internal Medicine, Section of Gerontology and Geriatrics, VU University Medical Center, Amsterdam, The Netherlands. ${ }^{6}$ Institut de Myologie, Centre de Recherches en Myologie UMR 974 76, INSERM U974, CNRS FRE 3617, Sorbonne Universités, UPMC Université Paris 06, F-75013 Paris, France. ${ }^{7}$ Pôle Endocrinologie, Diabétologie et Nutrition, Institut de Recherches Expérimentales et Cliniques, Université Catholique de Louvain, B-1200 Brussels, Belgium.

Received: 13 October 2014 Accepted: 16 December 2014 Published: 23 December 2014

\section{References}

1. Bijlsma AY, Meskers CG, Ling CH, Narici M, Kurrle SE, Cameron ID, Westendorp RG, Maier AB: Defining sarcopenia: the impact of different diagnostic criteria on the prevalence of sarcopenia in a large middle aged cohort. Age (Dordr) 2013, 35(3):871-881.

2. Taekema DG, Gussekloo J, Maier AB, Westendorp RG, de Craen AJ: Handgrip strength as a predictor of functional, psychological and social health. A prospective population-based study among the oldest old. Age Ageing 2010, 39(3):331-337.

3. Szulc P, Munoz F, Marchand F, Chapurlat R, Delmas PD: Rapid loss of appendicular skeletal muscle mass is associated with higher all-cause mortality in older men: the prospective MINOS study. Am J Clin Nutr 2010, 91(5):1227-1236.

4. Ling CH, Taekema D, de Craen AJ, Gussekloo J, Westendorp RG, Maier AB: Handgrip strength and mortality in the oldest old population: the Leiden 85-plus study. CMAJ : Can Med Assoc J J Assoc Med Can 2010, 182(5):429-435.

5. Sayer AA, Robinson SM, Patel HP, Shavlakadze T, Cooper C, Grounds MD: New horizons in the pathogenesis, diagnosis and management of sarcopenia. Age Ageing 2013, 42(2):145-150.

6. Janssen I, Heymsfield SB, Wang ZM, Ross R: Skeletal muscle mass and distribution in 468 men and women aged 18-88 yr. J Appl Physiol (1985) 2000, 89(1):81-88.

7. Wang H, Listrat A, Meunier B, Gueugneau M, Coudy-Gandilhon C, Combaret L, Taillandier D, Polge C, Attaix D, Lethias C, Taillandier D, Polge C, Attaix D, Lethias C, Lee K, Goh KL, Béchet D: Apoptosis in capillary endothelial cells in ageing skeletal muscle. Aging Cell 2014, 13(2):254-262.

8. Carosio S, Berardinelli MG, Aucello M, Musaro A: Impact of ageing on muscle cell regeneration. Ageing Res Rev 2011, 10(1):35-42.

9. Narici MV, Maffulli N: Sarcopenia: characteristics, mechanisms and functional significance. Br Med Bull 2010, 95:139-159.
10. Petersen KF, Befroy D, Dufour S, Dziura J, Ariyan C, Rothman DL, DiPietro L, Cline GW, Shulman Gl: Mitochondrial dysfunction in the elderly: possible role in insulin resistance. Science 2003, 300(5622):1140-1142.

11. Short KR, Bigelow ML, Kahl J, Singh R, Coenen-Schimke J, Raghavakaimal S, Nair KS: Decline in skeletal muscle mitochondrial function with aging in humans. Proc Natl Acad Sci U S A 2005, 102(15):5618-5623.

12. Gueugneau M, Coudy-Gandilhon C, Theron L, Meunier B, Barboiron C, Combaret L, Taillandier D, Polge C, Attaix D, Picard B, Verney J, Roche F, Féasson L, Barthélémy JC, Béchet D: Skeletal muscle lipid content and oxidative activity in relation to muscle fiber type in aging and metabolic syndrome. J Gerontol A Biol Sci Med Sci 2014. doi:10.1093/gerona/glu086.

13. Lee CK, Klopp RG, Weindruch R, Prolla TA: Gene expression profile of aging and its retardation by caloric restriction. Science 1999, 285(5432):1390-1393.

14. Baraibar MA, Gueugneau M, Duguez S, Butler-Browne G, Bechet D, Friguet B: Expression and modification proteomics during skeletal muscle ageing. Biogerontology 2013, 14(3):339-352.

15. Piec I, Listrat A, Alliot J, Chambon C, Taylor RG, Bechet D: Differential proteome analysis of aging in rat skeletal muscle. FASEB $J$ : Off Publ Fed Am Soc Exp Biol 2005, 19(9):1143-1145.

16. Capitanio D, Vasso M, Fania C, Moriggi M, Vigano A, Procacci P, Magnaghi V, Gelfi C: Comparative proteomic profile of rat sciatic nerve and gastrocnemius muscle tissues in ageing by 2-D DIGE. Proteomics 2009, 9(7):2004-2020.

17. Doran P, O'Connell K, Gannon J, Kavanagh M, Ohlendieck K: Opposite pathobiochemical fate of pyruvate kinase and adenylate kinase in aged rat skeletal muscle as revealed by proteomic DIGE analysis. Proteomics 2008, 8(2):364-377.

18. Gannon J, Doran P, Kirwan A, Ohlendieck K: Drastic increase of myosin light chain MLC-2 in senescent skeletal muscle indicates fast-to-slow fibre transition in sarcopenia of old age. Eur J Cell Biol 2009, 88(11):685-700.

19. O'Connell K, Ohlendieck K: Proteomic DIGE analysis of the mitochondriaenriched fraction from aged rat skeletal muscle. Proteomics 2009, 9(24):5509-5524.

20. Gelfi C, Vigano A, Ripamonti M, Pontoglio A, Begum S, Pellegrino MA, Grassi $B$, Bottinelli $R$, Wait $R$, Cerretelli $P$ : The human muscle proteome in aging. J Proteome Res 2006, 5(6):1344-1353.

21. Staunton L, Zweyer M, Swandulla D, Ohlendieck K: Mass spectrometrybased proteomic analysis of middle-aged vs. aged vastus lateralis reveals increased levels of carbonic anhydrase isoform 3 in senescent human skeletal muscle. Int J Mol Med 2012, 30(4):723-733.

22. Berger MJ, Doherty TJ: Sarcopenia: prevalence, mechanisms, and functional consequences. Interdiscip Top Gerontol 2010, 37:94-114.

23. Theron L, Gueugneau M, Coudy C, Viala D, Bijlsma A, Butler-Browne G, Maier $A$, Bechet $D$, Chambon C: Label-free quantitative protein profiling of vastus lateralis muscle during human aging. Mol Cell Proteomics: MCP 2014, 13(1):283-294.

24. Martin AF, Rabinowitz M, Blough R, Prior G, Zak R: Measurements of halflife of rat cardiac myosin heavy chain with leucyl-tRNA used as precursor pool. J Biol Chem 1977, 252(10):3422-3429.

25. Neti G, Novak SM, Thompson VF, Goll DE: Properties of easily releasable myofilaments: are they the first step in myofibrillar protein turnover? Am J Physiol Cell Physiol 2009, 296(6):C1383-C1390.

26. Wei $B$, Jin JP: Troponin $T$ isoforms and posttranscriptional modifications: evolution, regulation and function. Arch Biochem Biophys 2011, 505(2):144-154.

27. Pallavicini A, Kojic S, Bean C, Vainzof M, Salamon M, levolella C, Bortoletto G, Pacchioni B, Zatz M, Lanfranchi G, Faulkner G, Valle G: Characterization of human skeletal muscle Ankrd2. Biochem Biophys Res Commun 2001, 285 (2):378-386.

28. Hayashi C, Ono Y, Doi N, Kitamura F, Tagami M, Mineki R, Arai T, Taguchi H, Yanagida M, Hirner S, Labeit D, Labeit S, Sorimachi H: Multiple molecular interactions implicate the connectin/titin N2A region as a modulating scaffold for p94/calpain 3 activity in skeletal muscle. J Biol Chem 2008, 283(21):14801-14814.

29. Belgrano A, Rakicevic L, Mittempergher L, Campanaro S, Martinelli VC, Mouly V, Valle G, Kojic S, Faulkner G: Multi-tasking role of the mechanosensing protein Ankrd2 in the signaling network of striated muscle. PLoS One 2011, 6(10):e25519.

30. Tsukamoto Y, Senda T, Nakano T, Nakada C, Hida T, Ishiguro N, Kondo G, Baba T, Sato K, Osaki M, Mori S, Ito H, Moriyama M: Arpp, a new homolog of carp, is preferentially expressed in type 1 skeletal muscle fibers and is markedly induced by denervation. Lab Investig 2002, 82(5):645-655. 
31. Verdijk LB, Koopman R, Schaart G, Meijer K, Savelberg HH, van Loon LJ: Satellite cell content is specifically reduced in type II skeletal muscle fibers in the elderly. Am J Physiol Endocrinol Metab 2007, 292(1):E151-E157.

32. Dreyer HC, Blanco CE, Sattler FR, Schroeder ET, Wiswell RA: Satellite cell numbers in young and older men 24 hours after eccentric exercise. Muscle Nerve 2006, 33(2):242-253.

33. Lee WS, Cheung WH, Qin L, Tang N, Leung KS: Age-associated decrease of type IIA/B human skeletal muscle fibers. Clin Orthop Relat Res 2006, 450:231-237.

34. Sato T, Akatsuka H, Kito K, Tokoro Y, Tauchi H, Kato K: Age changes in size and number of muscle fibers in human minor pectoral muscle. Mech Ageing Dev 1984, 28(1):99-109.

35. Frontera WR, Hughes VA, Fielding RA, Fiatarone MA, Evans WJ, Roubenoff R: Aging of skeletal muscle: a 12-yr longitudinal study. J Appl Physiol 2000, 88(4):1321-1326

36. Lexell J, Taylor CC, Sjostrom M: What is the cause of the ageing atrophy? Total number, size and proportion of different fiber types studied in whole vastus lateralis muscle from 15- to 83 -year-old men. J Neurol Sci 1988, 84(2-3):275-294.

37. Kosek DJ, Kim JS, Petrella JK, Cross JM, Bamman MM: Efficacy of 3 days/wk resistance training on myofiber hypertrophy and myogenic mechanisms in young vs. older adults. J Appl Physiol (1985) 2006, 101(2):531-544.

38. Coggan AR, Spina RJ, King DS, Rogers MA, Brown M, Nemeth PM, Holloszy JO: Skeletal muscle adaptations to endurance training in 60- to 70-yr-old men and women. J Appl Physiol (1985) 1992, 72(5):1780-1786.

39. Berthier C, Blaineau S: Supramolecular organization of the subsarcolemmal cytoskeleton of adult skeletal muscle fibers. A review. Biol Cell Auspices Eur Cell Biol Org 1997, 89(7):413-434.

40. Ervasti JM: Costameres: the Achilles' heel of Herculean muscle. J Biol Chem 2003, 278(16):13591-13594.

41. Humphries JD, Wang P, Streuli C, Geiger B, Humphries MJ, Ballestrem C: Vinculin controls focal adhesion formation by direct interactions with talin and actin. J Cell Biol 2007, 179(5):1043-1057.

42. Carisey A, Ballestrem C: Vinculin, an adapter protein in control of cell adhesion signalling. Eur J Cell Biol 2011, 90(2-3):157-163.

43. Coghill ID, Brown S, Cottle DL, McGrath MJ, Robinson PA, Nandurkar HH, Dyson JM, Mitchell CA: FHL3 is an actin-binding protein that regulates alpha-actinin-mediated actin bundling: FHL3 localizes to actin stress fibers and enhances cell spreading and stress fiber disassembly. J Biol Chem 2003, 278(26):24139-24152.

44. Samson T, Smyth N, Janetzky S, Wendler O, Muller JM, Schule R, von der Mark H, von der Mark K, Wixler V: The LIM-only proteins FHL2 and FHL3 interact with alpha- and beta-subunits of the muscle alpha7beta1 integrin receptor. J Biol Chem 2004, 279(27):28641-28652.

45. Meeson AP, Shi X, Alexander MS, Williams RS, Allen RE, Jiang N, Adham IM, Goetsch SC, Hammer RE, Garry DJ: Sox15 and Fhl3 transcriptionally coactivate Foxk1 and regulate myogenic progenitor cells. EMBO J 2007 , 26(7):1902-1912.

46. Cottle DL, McGrath MJ, Cowling BS, Coghill ID, Brown S, Mitchell CA: FHL3 binds MyoD and negatively regulates myotube formation. J Cell Sci 2007, 120(Pt 8):1423-1435.

47. Wei L, Gallant EM, Dulhunty AF, Beard NA: Junctin and triadin each activate skeletal ryanodine receptors but junctin alone mediates functional interactions with calsequestrin. Int J Biochem Cell Biol 2009, 41(11):2214-2224

48. Lanner JT, Georgiou DK, Joshi AD, Hamilton SL: Ryanodine receptors: structure, expression, molecular details, and function in calcium release. Cold Spring Harb Perspect Biol 2010, 2(11):a003996.

49. Bellinger AM, Mongillo M, Marks AR: Stressed out: the skeletal muscle ryanodine receptor as a target of stress. J Clin Investig 2008, 118(2):445-453.

50. Gehlert S, Bungartz G, Willkomm L, Korkmaz Y, Pfannkuche K, Schiffer T, Bloch W, Suhr F: Intense resistance exercise induces early and transient increases in ryanodine receptor 1 phosphorylation in human skeletal muscle. PLoS One 2012, 7(11):e49326.

51. Leberer E, Timms BG, Campbell KP, MacLennan DH: Purification, calcium binding properties, and ultrastructural localization of the 53,000- and 160,000 (sarcalumenin)-dalton glycoproteins of the sarcoplasmic reticulum. J Biol Chem 1990, 265(17):10118-10124.

52. Mahaney JE, Weis $C P$, Grisham $C M$, Kutchai $H$ : Antibodies against the 53 $\mathrm{kDa}$ glycoprotein inhibit the rotational dynamics of both the $53 \mathrm{kDa}$ glycoprotein and the $\mathrm{Ca}(2+)$-ATPase in the sarcoplasmic reticulum membrane. Biochim Biophys Acta 1991, 1064(1):55-68.
53. Ferrington DA, Krainev AG, Bigelow DJ: Altered turnover of calcium regulatory proteins of the sarcoplasmic reticulum in aged skeletal muscle. J Biol Chem 1998, 273(10):5885-5891.

54. O'Connell K, Gannon J, Doran P, Ohlendieck K: Reduced expression of sarcalumenin and related $\mathrm{Ca} 2+-$ regulatory proteins in aged rat skeletal muscle. Exp Gerontol 2008, 43(10):958-961.

55. Frey N, Frank D, Lippl S, Kuhn C, Kogler H, Barrientos T, Rohr C, Will R, Muller OJ, Weiler H, Bassel-Duby R, Katus HA, Olson EN: Calsarcin-2 deficiency increases exercise capacity in mice through calcineurin/NFAT activation. $J$ Clin Investig 2008, 118(11):3598-3608.

56. Bizzarro V, Belvedere R, Dal Piaz F, Parente L, Petrella A: Annexin A1 induces skeletal muscle cell migration acting through formyl peptide receptors. PLoS One 2012, 7(10):e48246.

57. Leikina E, Melikov K, Sanyal S, Verma SK, Eun B, Gebert C, Pfeifer K, Lizunov VA, Kozlov MM, Chernomordik LV: Extracellular annexins and dynamin are important for sequential steps in myoblast fusion. J Cell Biol 2013, 200(1):109-123.

58. Cagliani R, Magri F, Toscano A, Merlini L, Fortunato F, Lamperti C, Rodolico C, Prelle A, Sironi M, Aguennouz M, Ciscato P, Uncini A, Moggio M, Bresolin N, Comi GP: Mutation finding in patients with dysferlin deficiency and role of the dysferlin interacting proteins annexin $\mathrm{A} 1$ and $\mathrm{A} 2$ in muscular dystrophies. Hum Mutat 2005, 26(3):283.

59. Voigt T, Sebald HJ, Schoenauer R, Levano S, Girard T, Hoppeler HH, Babiychuk EB, Draeger A: Annexin A1 is a biomarker of T-tubular repair in skeletal muscle of nonmyopathic patients undergoing statin therapy. FASEB J : Off Publ Fed Am Soc Exp Biol 2013, 27(6):2156-2164.

60. Bouter A, Gounou C, Berat R, Tan S, Gallois B, Granier T, d'Estaintot BL, Poschl E, Brachvogel B, Brisson AR: Annexin-A5 assembled into two-dimensional arrays promotes cell membrane repair. Nat Commun 2011, 2:270.

61. Sen N, Spitzer AR, Chander A: Calcium-dependence of synexin binding may determine aggregation and fusion of lamellar bodies. Biochem $J$ 1997, 322(Pt 1):103-109.

62. Wang L, Dong Z, Huang B, Zhao B, Wang H, Zhao J, Kung H, Zhang S, Miao $\mathrm{J}$ : Distinct patterns of autophagy evoked by two benzoxazine derivatives in vascular endothelial cells. Autophagy 2010, 6(8):1115-1124.

63. Board PG, Coggan M, Chelvanayagam G, Easteal S, Jermiin LS, Schulte GK, Danley DE, Hoth LR, Griffor MC, Kamath AV, Rosner MH, Chrunyk BA, Perregaux DE, Gabel CA, Geoghegan KF, Pandit J: Identification, characterization, and crystal structure of the Omega class glutathione transferases. J Biol Chem 2000, 275(32):24798-24806.

64. Dulhunty A, Gage P, Curtis S, Chelvanayagam G, Board P: The glutathione transferase structural family includes a nuclear chloride channel and a ryanodine receptor calcium release channel modulator. J Biol Chem 2001, 276(5):3319-3323.

65. Nuss JE, Amaning JK, Bailey CE, DeFord JH, Dimayuga VL, Rabek JP, Papaconstantinou J: Oxidative modification and aggregation of creatine kinase from aged mouse skeletal muscle. Aging 2009, 1(6):557-572.

66. Kelly TJ, Souza AL, Clish CB, Puigserver P: A hypoxia-induced positive feedback loop promotes hypoxia-inducible factor 1alpha stability through miR-210 suppression of glycerol-3-phosphate dehydrogenase 1-like. Mol Cell Biol 2011, 31(13):2696-2706.

67. Orosz F, Olah J, Ovadi J: Triosephosphate isomerase deficiency: new insights into an enigmatic disease. Biochim Biophys Acta 2009, 1792(12):1168-1174

68. Hipkiss AR: Energy metabolism and ageing regulation: metabolically driven deamidation of triosephosphate isomerase may contribute to proteostatic dysfunction. Ageing Res Rev 2011, 10(4):498-502.

69. Fischer H, Gustafsson T, Sundberg CJ, Norrbom J, Ekman M, Johansson O, Jansson E: Fatty acid binding protein 4 in human skeletal muscle. Biochem Biophys Res Commun 2006, 346(1):125-130.

70. Luiken JJ, Koonen DP, Coumans WA, Pelsers MM, Binas B, Bonen A, Glatz JF: Long-chain fatty acid uptake by skeletal muscle is impaired in homozygous, but not heterozygous, heart-type-FABP null mice. Lipids 2003, 38(4):491-496.

71. Erbay E, Babaev VR, Mayers JR, Makowski L, Charles KN, Snitow ME, Fazio S, Wiest MM, Watkins SM, Linton MF, Hotamisligil GS: Reducing endoplasmic reticulum stress through a macrophage lipid chaperone alleviates atherosclerosis. Nat Med 2009, 15(12):1383-1391.

72. Peterson CM, Johannsen DL, Ravussin E: Skeletal muscle mitochondria and aging: a review. J Aging Res 2012, 2012:194821. 
73. Rhee SG, Woo HA, Kil IS, Bae SH: Peroxiredoxin functions as a peroxidase and a regulator and sensor of local peroxides. J Biol Chem 2012, 287(7):4403-4410.

74. Murakami K, Ichinohe Y, Koike M, Sasaoka N, lemura S, Natsume T, Kakizuka A: VCP is an integral component of a novel feedback mechanism that controls intracellular localization of catalase and $\mathrm{H} 2 \mathrm{O} 2$ Levels. PLoS One 2013, 8(2):e56012.

75. Wilhelmus MM, Nijland PG, Drukarch B, de Vries HE, van Horssen J: Involvement and interplay of Parkin, PINK1, and DJ1 in neurodegenerative and neuroinflammatory disorders. Free Radic Biol Med 2012, 53(4):983-992

76. Andres-Mateos E, Perier C, Zhang L, Blanchard-Fillion B, Greco TM, Thomas B, Ko HS, Sasaki M, Ischiropoulos H, Przedborski S, Dawson TM, Dawson VL: DJ-1 gene deletion reveals that DJ-1 is an atypical peroxiredoxin-like peroxidase. Proc Natl Acad Sci U S A 2007, 104(37):14807-14812.

77. Thomas KJ, McCoy MK, Blackinton J, Beilina A, van der Brug M, Sandebring A, Miller D, Maric D, Cedazo-Minguez A, Cookson MR: DJ-1 acts in parallel to the PINK1/parkin pathway to control mitochondrial function and autophagy. Hum Mol Genet 2011, 20(1):40-50.

78. Altun M, Edstrom E, Spooner E, Flores-Moralez A, Bergman E, Tollet-Egnell P, Norstedt G, Kessler BM, Ulfhake B: Iron load and redox stress in skeletal muscle of aged rats. Muscle Nerve 2007, 36(2):223-233.

79. Budas $\mathrm{GR}$, Disatnik MH, Chen $\mathrm{CH}$, Mochly-Rosen D: Activation of aldehyde dehydrogenase $2(\mathrm{ALDH} 2)$ confers cardioprotection in protein kinase $\mathrm{C}$ epsilon (PKCvarepsilon) knockout mice. J Mol Cell Cardiol 2010, 48(4):757-764

80. Barski OA, Tipparaju SM, Bhatnagar A: The aldo-keto reductase superfamily and its role in drug metabolism and detoxification. Drug Metab Rev 2008, 40(4):553-624

81. Ramana KV: ALDOSE REDUCTASE: new insights for an old enzyme. Biomol Concepts 2011, 2(1-2):103-114.

82. Pandey S, Srivastava SK, Ramana KV: A potential therapeutic role for aldose reductase inhibitors in the treatment of endotoxin-related inflammatory diseases. Exp Opin Investig Drugs 2012, 21(3):329-339.

83. Yoshida A, Rzhetsky A, Hsu LC, Chang C: Human aldehyde dehydrogenase gene family. Eur J Biochem FEBS 1998, 251(3):549-557.

84. Forte-McRobbie C, Pietruszko R: Human glutamic-gamma-semialdehyde dehydrogenase. Kinetic mechanism. Biochem J 1989, 261(3):935-943.

85. Kampinga HH, Hageman J, Vos MJ, Kubota H, Tanguay RM, Bruford EA, Cheetham ME, Chen B, Hightower LE: Guidelines for the nomenclature of the human heat shock proteins. Cell Stress Chaperones 2009, 14(1):105-111.

86. Vos MJ, Hageman J, Carra S, Kampinga HH: Structural and functional diversities between members of the human HSPB, HSPH, HSPA, and DNAJ chaperone families. Biochemistry 2008, 47(27):7001-7011.

87. Doran P, Gannon J, O'Connell K, Ohlendieck K: Aging skeletal muscle shows a drastic increase in the small heat shock proteins alphaBcrystallin/HspB5 and cvHsp/HspB7. Eur J Cell Biol 2007, 86(10):629-640.

88. Mymrikov EV, Seit-Nebi AS, Gusev NB: Large potentials of small heat shock proteins. Physiol Rev 2011, 91(4):1123-1159.

89. Acunzo J, Katsogiannou M, Rocchi P: Small heat shock proteins HSP27 (HspB1), alphaB-crystallin (HspB5) and HSP22 (HspB8) as regulators of cell death. Int J Biochem Cell Biol 2012, 44(10):1622-1631.

90. Kim YE, Hipp MS, Bracher A, Hayer-Hartl M, Hartl FU: Molecular chaperone functions in protein folding and proteostasis. Annu Rev Biochem 2013, 82:323-355

91. Senf SM, Dodd SL, McClung JM, Judge AR: Hsp70 overexpression inhibits NF-kappaB and Foxo3a transcriptional activities and prevents skeletal muscle atrophy. FASEB J : Off Publ Fed Am Soc Exp Biol 2008, 22(11):3836-3845.

92. McArdle A, Dillmann WH, Mestril R, Faulkner JA, Jackson MJ: Overexpression of HSP70 in mouse skeletal muscle protects against muscle damage and age-related muscle dysfunction. FASEB $J$ : Off Publ Fed Am Soc Exp Biol 2004, 18(2):355-357.

93. Miyabara EH, Martin JL, Griffin TM, Moriscot AS, Mestril R: Overexpression of inducible 70-kDa heat shock protein in mouse attenuates skeletal muscle damage induced by cryolesioning. Am J Physiol Cell Physiol 2006, 290(4):C1128-C1138

94. losefson O, Sharon S, Goloubinoff P, Azem A: Reactivation of protein aggregates by mortalin and Tid1-the human mitochondrial Hsp70 chaperone system. Cell Stress Chaperones 2012, 17(1):57-66.
95. Taipale M, Jarosz DF, Lindquist S: HSP90 at the hub of protein homeostasis: emerging mechanistic insights. Nat Rev Mol Cell Biol 2010, 11(7):515-528.

96. Lombardi A, Silvestri E, Cioffi F, Senese R, Lanni A, Goglia F, de Lange P, Moreno M: Defining the transcriptomic and proteomic profiles of rat ageing skeletal muscle by the use of a cDNA array, 2D- and Blue nativePAGE approach. J Proteome 2009, 72(4):708-721.

97. Boyan BD, Chen J, Schwartz Z: Mechanism of Pdia3-dependent 1alpha,25dihydroxy vitamin D3 signaling in musculoskeletal cells. Steroids 2012, 77 (10):892-896.

98. Chen J, Lobachev KS, Grindel BJ, Farach-Carson MC, Hyzy SL, El-Baradie KB, Olivares-Navarrete R, Doroudi M, Boyan BD, Schwartz Z: Chaperone properties of pdia3 participate in rapid membrane actions of 1alpha,25dihydroxyvitamin d3. Mol Endocrinol 2013, 27(7):1065-1077.

99. Muir SW, Montero-Odasso M: Effect of vitamin D supplementation on muscle strength, gait and balance in older adults: a systematic review and meta-analysis. J Am Geriatr Soc 2011, 59(12):2291-2300.

100. Attaix D, Combaret L, Bechet D, Taillandier D: Role of the ubiquitinproteasome pathway in muscle atrophy in cachexia. Curr Opin Support Palliative Care 2008, 2(4):262-266.

101. Bechet D, Tassa A, Taillandier D, Combaret L, Attaix D: Lysosomal proteolysis in skeletal muscle. Int J Biochem Cell Bio/ 2005, 37(10):2098-2114.

102. Attaix D, Bechet D: FoxO3 controls dangerous proteolytic liaisons. Cell Metab 2007, 6(6):425-427.

103. Meyer $H$, Bug M, Bremer S: Emerging functions of the VCP/p97 AAAATPase in the ubiquitin system. Nat Cell Biol 2012, 14(2):117-123.

104. Ye Y, Meyer HH, Rapoport TA: The AAA ATPase Cdc48/p97 and its partners transport proteins from the ER into the cytosol. Nature 2001, 414(6864):652-656.

105. Xu S, Peng G, Wang Y, Fang S, Karbowski M: The AAA-ATPase p97 is essential for outer mitochondrial membrane protein turnover. Mol Biol Cell 2011, 22(3):291-300.

106. Indig FE, Partridge JJ, von Kobbe C, Aladjem MI, Latterich M, Bohr VA: Werner syndrome protein directly binds to the AAA ATPase p97/NCP in an ATP-dependent fashion. J Struct Biol 2004, 146(1-2):251-259.

107. Kim J, Lowe T, Hoppe T: Protein quality control gets muscle into shape. Trends Cell Biol 2008, 18(6):264-272.

108. Ye Y: Diverse functions with a common regulator: ubiquitin takes command of an AAA ATPase. J Struct Biol 2006, 156(1):29-40.

109. Krick R, Bremer S, Welter E, Schlotterhose P, Muehe Y, Eskelinen EL, Thumm M: Cdc48/p97 and Shp1/p47 regulate autophagosome biogenesis in concert with ubiquitin-like Atg8. J Cell Biol 2010, 190(6):965-973.

110. Tanaka A, Cleland MM, Xu S, Narendra DP, Suen DF, Karbowski M, Youle RJ: Proteasome and p97 mediate mitophagy and degradation of mitofusins induced by Parkin. J Cell Biol 2010, 191(7):1367-1380.

111. Altun M, Besche HC, Overkleeft HS, Piccirillo R, Edelmann MJ, Kessler BM, Goldberg AL, Ulfhake B: Muscle wasting in aged, sarcopenic rats is associated with enhanced activity of the ubiquitin proteasome pathway. J Biol Chem 2010, 285(51):39597-39608.

112. Bergink S, Toussaint W, Luijsterburg MS, Dinant C, Alekseev S, Hoeijmakers $J H$, Dantuma NP, Houtsmuller AB, Vermeulen W: Recognition of DNA damage by XPC coincides with disruption of the XPC-RAD23 complex. J Cell Biol 2012, 196(6):681-688

113. Wade SL, Auble DT: The Rad23 ubiquitin receptor, the proteasome and functional specificity in transcriptional control. Transcription 2010, 1(1):22-26.

114. Lei $Y$, Wen H, Ting JP: The NLR protein, NLRX1, and its partner, TUFM, reduce type I interferon, and enhance autophagy. Autophagy 2013, 9(3):432-433.

115. Besio R, Baratto MC, Gioia R, Monzani E, Nicolis S, Cucca L, Profumo A, Casella L, Basosi R, Tenni R, Rossi A, Forlino A: A Mn(II)-Mn(II) center in human prolidase. Biochim Biophys Acta 2013, 1834(1):197-204.

116. Zhang H, Wang Y, Li J, Yu J, Pu J, Li L, Zhang S, Peng G, Yang F, Liu P: Proteome of skeletal muscle lipid droplet reveals association with mitochondria and apolipoprotein a-I. J Proteome Res 2011, 10(10):4757-4768.

117. Bearden SE: Effect of aging on the structure and function of skeletal muscle microvascular networks. Microcirculation 2006, 13(4):279-288.

118. Scott HS, Chen H, Rossier C, Lalioti MD, Antonarakis SE: Isolation of a human gene (HES1) with homology to an Escherichia coli and a zebrafish protein that maps to chromosome 21q22.3. Hum Genet 1997, 99(5):616-623.

119. Aksoy P, Zhu MJ, Kalari KR, Moon I, Pelleymounter LL, Eckloff BW, Wieben ED, Yee VC, Weinshilboum RM, Wang L: Cytosolic 5'-nucleotidase III (NT5C3): gene sequence variation and functional genomics. Pharmacogenet Genomics 2009, 19(8):567-576. 
120. Sato Y, Probst HC, Tatsumi R, lkeuchi Y, Neuberger MS, Rada C: Deficiency in APOBEC2 leads to a shift in muscle fiber type, diminished body mass, and myopathy. J Biol Chem 2010, 285(10):7111-7118.

121. Sayd T, Morzel M, Chambon C, Franck M, Figwer P, Larzul C, Le Roy P, Monin G, Cherel P, Laville E: Proteome analysis of the sarcoplasmic fraction of pig semimembranosus muscle: implications on meat color development. J Agric Food Chem 2006, 54(7):2732-2737.

122. Vizcaino JA, Deutsch EW, Wang R, Csordas A, Reisinger F, Rios D, Dianes JA, Sun Z, Farrah T, Bandeira N, Binz PA, Xenarios I, Eisenacher M, Mayer G, Gatto L, Campos A, Chalkley RJ, Kraus HJ, Albar JP, Martinez-Bartolomé S, Apweiler R, Omenn GS, Martens L, Jones AR, Hermjakob H: ProteomeXchange provides globally coordinated proteomics data submission and dissemination. Nat Biotechnol 2014, 32(3):223-226.

123. Szklarczyk D, Franceschini A, Kuhn M, Simonovic M, Roth A, Minguez P, Doerks $T$, Stark M, Muller J, Bork P, Jensen $\sqcup$, von Mering C: The STRING database in 2011: functional interaction networks of proteins, globally integrated and scored. Nucleic Acids Res 2011, 39(Database issue):D561-D568.

doi:10.1186/1471-2164-15-1165

Cite this article as: Gueugneau et al:: Proteomics of muscle

chronological ageing in post-menopausal women. BMC Genomics 2014 15:1165.

\section{Submit your next manuscript to BioMed Central and take full advantage of:}

- Convenient online submission

- Thorough peer review

- No space constraints or color figure charges

- Immediate publication on acceptance

- Inclusion in PubMed, CAS, Scopus and Google Scholar

- Research which is freely available for redistribution 